\title{
Eesti kunstnikud ajakirjandusgraafikas 1930. aastail
}

\begin{abstract}
Merle Talvik
Teesid: Aastail 1930-1940 oli eesti ajakirjandusgraafikas esimene tõusulaine. Kunstnikkonnas suurenes kodumaal õppinute tähtsus, kujunesid välja kindla loomingulise ilmega koolkonnad: Tallinna kunstnikud, kes olid valdavalt saanud hariduse Riigi Kunsttööstuskoolis ning andsid näo Tallinnas ilmuvatele ajakirjadele, ning Tartu graafikud, kes olid saanud hariduse kõrgemas kunstikoolis Pallas ning kujundasid Tartus ilmuvate ajakirjade ilmet. Nende koolkondade ühisjooneks kujunes art déco. Kunsttööstuskooli õppekavade eeskujuks olid Peterburi Stieglitzi kunsttööstuskooli õppekavad, mida iseloomustas süsteemne kirja- ja ornamendiõpetus. Ohtralt kasutati ka etnograafilist ornamenti. Tartu koolkond andis palju huvitavaid ja isikupäraseid kunstnikke, rahvuslik propaganda oli nende töödes vähem ilmne ja kunstnike loominguline vabadus suurem, kuid kiri süstemaatilise õpetuse puudumise tõttu sageli ebaprofessionaalne.
\end{abstract}

Märksõnad: ajakirjade graafiline kujundamine, ajakirjandusgraafika, art déco, eesti kunst, kirjakunst, kõrgem kunstikool Pallas, Riigi Kunsttööstuskool

\section{Sissejuhatus}

Ajakirjandusgraafika kujundusgraafika osana hõlmab endas nii ajakirjades kui ka ajalehtedes ilmunud kunstnike jooniseid. Käesolevas artiklis uuritakse ajakirjades ilmunud autoritöid, kuid jäetakse kõrvale ajalehtedes ilmunud tööd. Käsitletavatel töödel on sotsiaalne, poliitiline ja majanduslik tähendus, kuid artiklis hinnatakse töid eelkõige kunstilisest aspektist.

Aastail 1930-1940 oli eesti kujundusgraafika esimene tõusulaine. See oli periood, mil kunsti märksõnadeks olid kord, monumentaalsus, rahvuslikkus, klassika ja hierarhia (Borsi 1987: 13). Eestis väljendusid need eriti selgelt arhitektuuris (Kalm 1994: 93-136; Kodres 2001: 236-240), aga ka tarbekunstis ja -graafikas. Noor, oma identiteeti kaitsma sunnitud eesti rahvuskultuur oli võtnud suuna internatsionaalsusele rahvuslikkuse kaudu, kirjutab Tiina 
Abel (1995: 143), mis tähendab, et lühikese aja jooksul tuli saavutada süntees raskesti defineeritava rahvusliku traditsiooni ja teatava "normina" käsitletava rahvusvahelise kultuurikogemuse vahel. Vaatamata sellele, et Eesti ise oli pigem agraarriik, arenes majandus tol ajal kiiresti, hoogustusid turism ja puhkekultuur ning populariseerus linlik elulaad ehk urban lifestyle. Kõigesse sellesse tuli kujundada oma suhe, kusjuures selles protsessis oli oluline ajakirjade osa.

1968. aastal tõi Boriss Bernštein eesti kunstiteadusesse Georgi Gatševi tollal suhteliselt uudse rahvuskultuuri kiirendatud arengu mõiste (Bernštein 1979: 128). Mõned aastad hiljem kirjutas B. Bernstein juba G. Gatševiga polemiseerides:

Kiirendatud arengu olemus seisneb selles, et antud etnilise ühenduse kultuur teeb tasa vahelejäänu, toetudes võõrale kogemusele ja omandades seda omal kombel. Seda kultuurikogemust omavad ühendused võivad olla ette jõudnud ühe, kahe, kolme faasi võrra; niisugusel juhul ei korda kiirendatud areng lühidalt kõiki vahepealseid faase, vaid jätab neid vahele. Seejuures arenev kultuur võtab võoraid kogemusi vastu valikuliselt - vastavalt oma võimalustele ja oma vajadustele, mille hulgas kaugeltki mitte viimast rolli ei mängi rahvusliku eneseteostamise ja järelikult oma erijoonte tunnetamise vajadus. [---] Seejuures toimub võorra kunstikogemuse evitamine, olgugi valikuline, selle kunstikultuuri tü̈̈bi piires, mis antud ajastul domineerib ja vastab kiirendatud korras areneva etnosotsiaalse organismi kujunevatele sotsiaalsetele struktuuridele (Bernštein 1977: 27).

Kiirendatud kultuuriareng leidis aset 1918. aastal iseseisvunud Eestis. See asjaolu seadis paratamatult eesti kunstnike ette loova jäljendamise ja interpreteerimise probleemi. Euroopa avangardkunsti peaharud saabusid kõikuvale pinnale, kus järjepidev kunstikultuur oli alles kujunemas. Juri Lotman on kirjutanud:

Iga uus samm kultuuri arengus suurendab, aga ei ammenda kultuuriinformatsiooni väärtust ning järelikult suurendab ka - mitte ei vähendatema seesmist mä̈̈ramatust, nende võimaluste kogumit, mis tema realisatsiooni käigus jäävad teostamata (Lotman 1999: 71-72).

Tsitaadist tulenevalt suurendab iga uue väärtuse sissetung seesmist määramatust, muutes kultuuri arengu ootamatuks. Niisugustes tingimustes kujunes välja meie rahvusliku kunsti esimene tõsiseltvõetav koolkond.

B. Bernštein (1979: 128) väidab ka, et rahvuslik koolkond peab eluvõimeliseks saamiseks rajama ja välja arendama kunstielu täieliku struktuuri, mis 
kätkeb peale kunstikommunikatsiooni kõiki enese taastootmise, enesereguleerimise põhilisi mehhanisme. Hetke, mil struktuur on valmis, võib määratleda kui piiri, mille taga läheb kiirendatud areng üle normaalseks. Eesti kunstis moodustusid selle skeemi peamised komponendid aastail 1920-1930, seega rajati rahvuslik kunstistruktuur esimese kümne iseseisvusaastaga. Sellest lähtudes on oluline märkida, et ajal, mil jõudis lõpule eesti kunstielu struktuuri väljakujunemine ning kiirendatud areng muutus normaalseks, stabiliseerusid ka mõlema kunstiõppeasutuse, keskastme koolitust andva Tallinna (1924. aastast Riigi) Kunsttööstuskooli ja Tartus asuva Kõrgema Kunstikooli Pallas õppesüsteemid. Kunstnikkonnas suurenes kodumaal õppinute tähtsus, kujunesid välja kindlad loomingulised koolkonnad.

Samas kandis mõlema koolkonna kunstnike loomekeel ikkagi veel kiirendatud arengu jälgi. Riigi Kunsttööstuskool on enim mõjutanud meie tarbekunsti ja kujundusgraafika arengut. Kujundusgraafikat seostatigi tollal tarbekunsti ehk rakenduskunstiga, näiteks esinesid kujundusgraafikud oma töödega Rakenduskunstnike Ühingu (RaKÜ) ${ }^{1}$ näitustel. Pallase koolkond oli esimene normaalseis arengutingimustes kujunenud maalikunsti ja skulptuuri koolkond. Selle kooli lõpetas ka rida andekaid graafikuid, mõnedki neist tegelesid kujundusgraafikaga. Kujundusgraafikute kunstialase ettevalmistuse osas tuleb mainida, et vanemas põlvkonnas olid kindla erialase ettevalmistusega vaid üksikud - nimetada julgen vaid Guido Mambergi ${ }^{2}$ ja Edmond Arnold Blumenfeldti. ${ }^{3}$ Tänu majanduse ja kaubanduse kiirenenud arengule kerkis esile rida iseõppijaist kujundusgraafikuid.

Arvestatav osa trükitud kujundusgraafikast ilmus ajakirjades. Seega annab ajakirjandusgraafika analüüs üsna hea ülevaate tollasest kujundusgraafikast. Käesolevas artiklis keskendutakse Eestis 1930. aastate ajakirjandusgraafikutele. Neid käsitletakse koolkondade lõikes, tuginedes seisukohale, et kunstniku loomingu väljakujunemisel etendavad tema hariduse omandamise paik, kool ja õpetajad üsna suurt osa.

\section{Tallinna koolkond}

Kunsttööstuskool oli esimene süstemaatilist kunstiharidust andev õppeasutus Eestis. Varasemad käsitöökoolid ei pretendeerinud professionaalse kunsti tasemele ja ateljeekoolid piirdusid põhiliselt praktilise õpetusega. 19. sajandi teisel poolel oli kogu Euroopas tekkinud arvukalt kunsttööstuskoole, mis valmistasid ette kunstnikke üha uutele rajatavatele vabrikutele. Nende koolide õppetegevus oli ajastule iseloomulikult eklektilis-historitsistlikku laadi. Ometi oppisid tulevased kunstnikud neis koolides tehnilisi oskusi paljudel tarbekuns- 
tialadel ning omandasid vilumuse ornamendi- ja vormikujunduses, muutudes oma alal professionaalideks (Kirme 1975: 14).

Tallinna Kunsttööstuskooli õppekavade loomisel oli eeskujuks Parun Stieglitzi Tehnilise Joonistamise Keskõppeasutus, mis avati 1879. aastal Peterburis. Asutajaks oli suurtööstur, pankur ja kunstimetseen parun Alexander Stieglitz (1814-1884), kelle nimi oli tuntud ka Eestis. ${ }^{4}$ Stieglitzi kooli eesmärgiks oli valmistada ette joonistajaid-kujundajaid Venemaa tööstusele, mitte loovkunstnikke. Kool oli õppetingimuste poolest lihtrahvale vastuvõetavam kui teised Peterburi kunstiõppeasutused ning seal on hariduse saanud ligi 60 eestlast, nende hulgas Jaan Koort, Voldemar Mellik, Konrad Mägi, Nikolai Triik, Roman Nyman, Aleksander Tassa ja Günther Reindorff.

1912. aastal avas Stieglitzi kunsttööstuskooli kasvandik Voldemar Päts ${ }^{5}$ (1878-1958) koos kaaskondlastega Eesti Kunstiseltsi Graafiliste Kunstide kursused. 1914. aastal loodi kursuste baasil Tallinna Kunsttööstuskool, direktoriks valis kooli kuratoorium Voldemar Pätsi. Tallinna Kunsttööstuskoolis õpiti viis aastat ja selle lõpetajad pidid saama nn õpetatud joonistaja nimetuse. Esialgu õpetati üldaineid ja üldisi kunstiaineid, näiteks joonistamist, järk-järgult hakkasid lisanduma mitmesugused tarbekunstialad (Kirme 1994). Kunsttööstuskooli kritiseeriti vahepealseil aastail kõvasti. Mai Levini arvates on seejuures liialt lähtutud kujutavast kunstist. Koolile on ette heidetud rõhuasetust stiliseerimisele, ent ajalooliste stiilide õpetus vastas kooli spetsiifikale. Kunsttööstuskoolilt ei saanudki nõuda seda väljaõpet, mis anti kunstiakadeemias või eraateljees. Pallasega võrreldes olid kunsttööstuskoolis suhteliselt nõrgad kujutava kunsti harud, kuid samas üsna tugevad graafikapedagoogid (Levin \& Sirkel 1989: 5). 1920. aastal asus kunsttööstuskooli tööle Günther Reindorff (1889-1974). Algul oli ta joonistusõpetaja, 1922. aastast graafikaõppetöökoja juhataja.

Riigi Kunsttööstuskoolil olid ulatuslikud välissidemed Saksamaa kunstija tarbekunstikoolidega, mida peeti Euroopa parimaiks. Nende siht ja põhimõtted olid üldjoontes vastuvõetavad ka meile (ERA f 1108, n 6, s 843, L 147153). Nii õpilased kui ka õppejõud käisid enesetäiendamiseks välislähetustel. Edukamad G. Reindorffi oppilastest suunati edasi õppima: Paul Luhtein Leipzigi Graafikakunsti ja Raamatukujunduse Akadeemiasse, ${ }^{6}$ Gerda Hoffman ${ }^{7}$ Viini Akadeemiasse, ${ }^{8}$ Salome Trei ${ }^{9}$ Pallasesse (ERA f 1108, n 6, s 843, L 309, 310).

Riigi Kunsttööstuskooli õpilaste sulatamine kunstiellu algas juba õpiajal. Eriti suur oli graafika eriala õpilaste tööpõld. Nad osalesid raamatute illustreerimisel, ajakirjade kujundamisel ja võtsid edukalt osa reklaamtrükiste võistlustest. Kooli vilistlane Linda Ormesson ${ }^{10}$ andis koos õe Johannaga ${ }^{11}$ välja kodumajanduse ja kodukultuuri ajakirja Kaunis Kodu, mis ilmus aastail 1934- 
1938 ja tutvustas ka Riigi Kunsttööstuskooli vilistlaste tegevust (Toom 2004: 90). Suures osas kujundasid just Riigi Kunsttööstuskooli lõpetajad 1930. aastatel Tallinnas ilmunud ajakirjade visuaalse näo.

Tallinn kui pealinn oli poliitilise võimu keskpunkt ning võib öelda, et Tallinna ajakirjad olid Tallinna nägu. Üheks oluliseks jooneks, mis Tallinna ajakirju Tartu omadest eristas, oli rahvuslikkus. 1930. aastail asuti esteetilisi arusaamu riiklikult reguleerima. Mida tugevamini Konstantin Pätsi valitsus oma võimu kinnitas, seda selgemalt tulid esile kultuuri poliitilise ühtlustamise taotlused. Rahva varast ajalugu ja kunsti käsitleti idealiseeritult, romantilise paatosega. Valitsuse positiivsuse ja rahvustervikluse programmi toetavaks eeskujuks sobis kõige paremini rahvakunst. Teisest küljest oli huvi kasv rahvusliku ornamentika vastu mõnes mõttes kaitse välismaiste mõjude ja näidiste eest. $^{12}$

Huvi pärismaise ja rahvusliku kunsti vastu oli art déco ajastule üldomane. 1930. aastate Eestis nihkus rahvuslikkuse küsimus tulipunkti kõigil elualadel. Kunstis oli rahvusromantism jõudnud justkui teise faasi. Esimene faas langes ühte Noor-Eesti liikumisega. 1920. aastail, olukorras, kus iseseisvus oli saavutatud, oli aktuaalsem "eurooplaseks saamine", kas siis klassikalise või moodsa kaudu (Kodres 2001: 42). 1930. aastail tekkis aga juba teatud protestina vastuliikumine, mis nõudis eesti algupärase kultuuri aussetõstmist ja selle kasutamist kaasaegses kunstis. Rahvuslikkust propageerisid ajakirjad, kus Bernhard Linde, Johannes Semper, Adamson-Eric, Sten Karling, Rasmus Kangro-Pool jt võtsid sõna rahvuslikkuse küsimustes. Maaeluga seotud ajakirjad mõjutasid Eesti maakodude välimust, seega kogu kodumaa ilmet. Käimas oli nn kodukaunistamise hoogtöö ajastu, mis tähendas, et Eesti kehvad kodud taheti muuta ilusaiks, korralikeks ja armastusväärseiks nii oma sisult kui ka välisilmelt.

Riigi Kunsttööstuskooli põlvkonnale oli vaieldamatuks autoriteediks ornamendikujunduse ja kirjakunsti alal Günther Reindorff (1889-1974), kelle isikupärane rahvuslik käekiri kujunes välja vene rühmituse Mir Iskusstva ${ }^{13}$ raamatugraafikute loomingu mõjul. Viimased taotlesid kujunduses peenust, rafineeritust ja dekoratiivsust, koondades tähelepanu raamatu kaunistamisele ja allutades sellele teose sisulise tõlgitsuse. Joonistusliku külje peen viimistlus, kalligraafiline stilisatsioon, joonistatud kirja ilmekus ja ilu iseloomustavad Günther Reindorffi loomingut. G. Reindorff suutis oma graafilistes kujundustes luua tervikliku ornamendi rahvakunstist laenatud motiivide ${ }^{14}$ rakendamise abil ning ühendada kirja ja joonistuse rikkalikuks kunstiliseks ansambliks. Kirjal, ornamendil ja joonistusel on tihe side ning enamasti on ornament see, 

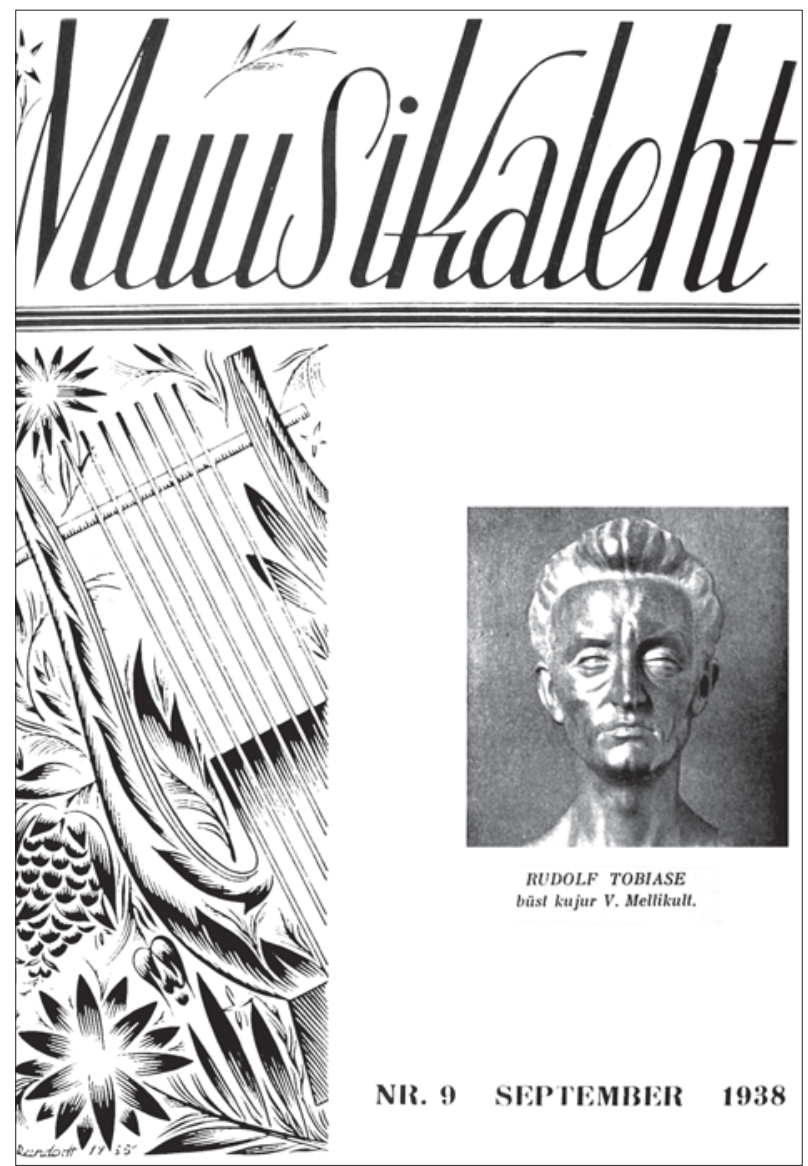

Joonis 1. Günther Reindorff. Muusikalehe 1938. aasta 9. numbri kaas.

mille vahendusel sulatatakse kujundus tervikuks. Kunstnik armastas ornamenti nii üldkompositsioonis kui ka üksikute tähtede kaunistamisel. Seejuures ei mõju tema kujundused taimornamendist aiana, nagu pahatihti juhtus eesti kujunduskunstis Teise maailmasõja järel. Ornamendi stiliseerimisel lähtub G. Reindorff eelkõige art décost. ${ }^{15}$ Tema töödele on iseloomulik dekoratiivsus, püüe esinduslikkusele, nurgelisust ümarustega kombineeriv stilisatsioon ja peen graafilisus.

G. Reindorff pani aluse kirjakunsti õpetamise süsteemsele metoodikale Eestis. 1920. aastate teisel poolel ja 1930. aastate algul kujunes G. Reindorffil välja eriline, ainult temale omane ehiskiri, mida iseloomustab tähtede põhijoonte kitsenemine allapoole. Kiri on tuletatud antiikvast ja gooti untsiaalist (Talvik 2005: 125), see on saanud mõjutusi ka skandinaavia ruunimärkidest 
ja vanavene glagoolitsast (Sakk 2004: iv-v). Sellist kirja hakkasid kasutama mitmed G. Reindorffi õpilased ja järgijad, sellest sai omamoodi eesti rahvuslik kiri. Kirjameistri õpilased kunsttööstuskoolist andsid oskusi edasi oma õpilastele ning nõnda kandus põlvest põlve edasi ka "eestipärane" kiri. Loomulikult oli tähtsaks kirjakunsti populariseerijaks meistri enda looming, mis haaras kaasa terveid ringkondi (Toots 1970: 10). Nii võibki G. Reindorffi õigustatult pidada eesti kirjagraafika isaks.

1928. aastal lõi Günther Reindorff Eesti Lauljate Liidu ajakirjale Muusikaleht tiitliillustratsiooni. Aastail 1936-1940 oli Muusikalehel elegantne kursiivkirjas pealkiri ornamentkaunistusega, millel esinevad kõik peamised art déco tunnused (joonis 1). Kahe viimase aastakäigu kujundus lihtsustus ja ornament kadus.

Aastail 1930-1935 kujundas Muusikalehte G. Reindorffi õpilane Johann Naha (1902-1982), kes õppis aastail 1923-1929 Riigi Kunsttööstuskooli graafikaosakonnas, kus lõpetas kuueaastase kursuse. Johann Naha varases loomingus väljendub selgelt G. Reindorffi mõju: kujundus on ornamentaalne ja tugineb kirjale, palju on kasutatud vinjette ja ehisinitsiaale. Hiljem muutub J. Naha käekiri vabamaks. Muusikalehele lõi ta nii rahvuslikus laadis ornamentvinjette kui ka vabamas stiilis linoollõikeid ja kirjakujundusi. Tema loomingut iseloomustab gravüürilikkus ja dekoratiivsus. Johann Naha on teinud kujunduse ka mitmele kristlikule ja kodumajanduslikule ajakirjale. Peale selle on ta loonud hulgaliselt reklaamgraafikat, millest suurem osa avaldati ajakirjades.

Õpiaastatel ja varases loomingus G. Reindorffi loomelaadist sügavalt mõjutatud, kuid hiljem oma isikupärase, äärmiselt selgele kirjale ja rangele arhitektoonikale tugineva laadi leidnud Paul Luhtein (sünd 1909) on produktiivne raamatu-, kirja- ja tarbegraafik. Tema looming on väga mahukas ja mitmepalgeline. Ta on loonud tarbegraafikat kõikidel aladel, kuid ka vabagraafikat ja kavandeid tarbekunstile. Riigi Kunsttööstuskooli astus ta 1924. aastal ning lõpetas selle 1930. aastal rakenduskunstnikuna. Kunstnik täiendas end aastail 1931-1932 riikliku stipendiaadina Leipzigi Graafika ja Raamatukunsti Akadeemias (õpetaja Walter Tiemann). Kunsttööstuskoolis omandatud dekoratiiv-ornamentaalsele laadile lisandub Leipzigi õpingute tulemusena kirja lihtsus ja tüpograafiapärasus, kompositsiooniliste lahenduste kainus ja funktsionaalsus, püüd tervikliku kujunduse poole. Need kaks vastandlikku meetodit määrasidki P. Luhteina kunstnikupalge. P. Luhtein oli kursis ka Dessaus asuva Bauhausi ${ }^{16}$ kunstikoolis toimuvaga, kuid ometi ei jätnud see kunstnikule sügavat jälge ning temast sai art décoliku traditsionalismi viljeleja (Sakk 


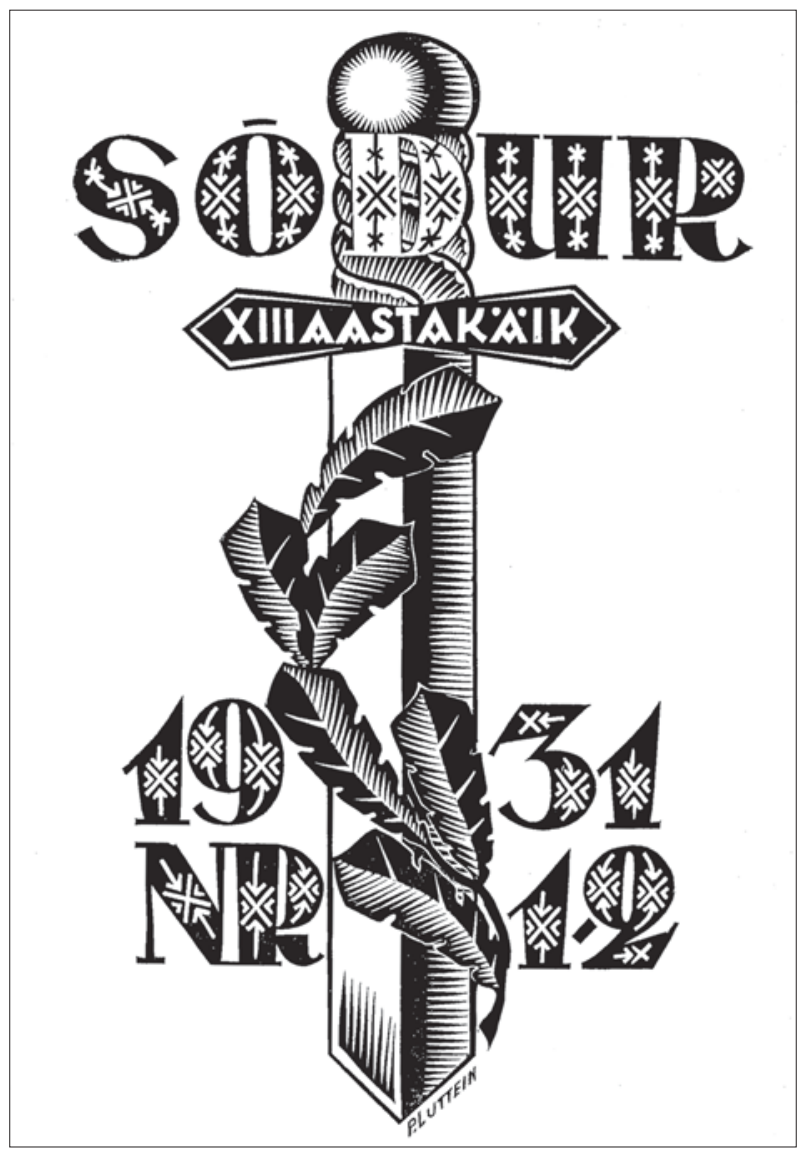

Joonis 2. Paul Luhtein. Ajakirja Sõdur 1931. aasta 12. numbri kaas.

2004: iv). Aastail 1932-1940 töötas ta Riigi Kunsttööstuskooli õppejõuna, hiljem aastakümneid Eesti NSV Riiklikus Kunstiinstituudis, kindlustades kujundusgraafikas neoklassitsistlik-art décoliku laadi püsimise kogu nõukogude aja.

1930. aastail kujundas P. Luhtein Oskar Kilgase tekstiilivabriku ${ }^{17}$ pakendeid ja reklaame ning hulgaliselt raamatuid ja ajakirju. Temalt pärinevad kümnekonna ajakirja kaanekujundused, neist tuntumad Välis-Eesti Almanak (1931-1934) ja Sõdur (1931-1934). Ajakirjade kaantel näeme funktsionaalselt jagatud pildipinda, plakatlikku värvikasutust ja selgesti loetavat ornamenteeritud antiikvakirja (joonis 2). Rahvuslik teema esineb kord ornamendil, kord piltkujutistel. Esiletõstmist väärib P. Luhteini 1930. aastail loodud elegantne reklaamgraafika. Ajakirja Teater (1939) tagumistel lehekülgedel avaldatud Oskar Kilgase siidsukkade ja kleidiriiete art décolikud reklaamid on suu- 
natud moodsale naisele. Kirjakujundus nendel P. Luhteini kuulutustel on kaunis ja õhuline, kursiivkirjas suurtähed moodustavad fantaasiarikkaid kaari.

Maalikunstnik ja graafik Hugo Lepik (1905-2001) lõpetas 1929. aastal edukalt Riigi Kunsttööstuskooli graafika ja litograafia erialal. Temagi oli G. Reindorffi õpilane. 1935. aastal täiendas H. Lepik end Berliini kõrgemas graafikakoolis. ${ }^{18}$ 1929. aastal hakkas ta tööle Riigi Kunsttööstuskooli õppejõuna, tegutsedes samas 1940. aastani. 1929. aastast töötas Hugo Lepik intensiivselt raamatugraafika alal ja tegi kaastööd ajakirjadele (nt kaanekujundused ja joonistused ajakirjale Sõdur (1929 ja 1933) ning kaanekujundused ajakirjadele Kaitse Kodu! (1929) ja Taluperenaine (1939)). Ajakirjale Varamu (1938) joonistas ta kaunid vinjetid, mis kordusid numbrist numbrisse.

Hugo Lepiku stiil on joonistuslikult korrektne ja graafiliselt peen. Vinjetid kujutavad enamasti loodusmotiive. Tiitlikujundus ajakirja Eesti Noorus 1938. aasta 2. numbrile koosneb korrapärasest antiikvakirjast ja etnograafilisest lillornamendist, mis on lahendatud ajastule ning koolkonnale omaselt.

Riigi Kunsttööstuskooli kasvandikest olid ajakirjade kujundajatena tegevad veel Werner Birkenfeldt (1903-1942), Eduard Salu (1906-1967), Ferdinand Liiv (1912-1948), Voldemar Tomassov (1906-1961), Axel Rossmann (18991974), Richard Pallas (1908-1951), Romulus Tiitus (1906-1982), Ferdinand Kask (1900-1941), Roman Haavamägi (1891-1964), Paul Liivak (1900-1942) ja Eugen Vaino (1909-1969).

Põhiliselt ajalehtedele, aga ka ajakirjadele tegi kaastööd Werner Birkenfeldt (Verny). Ta õppis 1927. aastal lühikest aega Riigi Kunsttööstuskoolis kivitrüki erialal. Verny kasutas eesti ajalehekujunduses ühena esimestest suuri tiitlijoonistusi ja fotomontaaži. Temast kujunes 1930. aastail väga tootlik ajaviitežanri joonistaja. Tema humoorikas, ent magusavõitu laad oli arusaadav laiale publikule. Verny kujundas ajakirja Kirilind kaaned (1939-1940), tegi vinjette, reklaamgraafikat, fotomontaaže, kaanekujundusi ja humoorikaid illustratsioone ajakirjale Huvitav Žurnaal, lõi kaaneillustratsioonid ajakirjadele Lood Elust (1932) ja Maaomavalitsus (1931).

Lühikest aega (1922. aastal) õppis Tallinna Kunsttööstuskoolis teinegi väga produktiivne ajakirjade kujundaja Axel Rossmann. Ta pärines trükitöölise perekonnast (isa August Rossmann oli aastail 1923-1932 Tallinna Kunsttööstuskooli trükitöö meister (Toom 2004: 28)). Axel Rossmann kujundas hulga ajakirjakaasi: Huvitav Žurnaal (1933-1935), Kõigile (1936), Käsitööleht (1932-1935), Kaitse Kodu! (1935-1939), Laste Rõõm (1931) jne. Tema loo- 
mingut iseloomustab mõningast dekoratiivsust ilmutav illustratiivne laad, mis on üsna sarnane nii Soome kui ka Läti naisteajakirjade kaanekujundustele, sageli esineb art décole iseloomulik motiiv - daam koerakese või linnukesega (joonis 4).

Richard Pallas lõpetas 1931. aastal kiitusega Riigi Kunsttööstuskooli dekoratiivmaali eriala ja viibis 1937. aastal riigi stipendiaadina Pariisis. Ta töötas põhiliselt reklaamikunstnikuna: kujundas vaateaknaid, näitusi ja ajalehekuulutusi, lõi plakateid ning tegi ajakirjade kaanekujundusi. Tema loomingule on omased dekoratiivsus ja rütmitaotlus, reklaampiltidel armastab kunstnik motiivide kordusi. Huvitava Žurnaali kaanekujundused on ajastule tüüpilised: 1937. aasta sügisnumbri kaanel näeme metsas aega veetvat naist, kes toetub puu najale, kasetüved moodustavad rütmilise korduse, figuur on lihtsustatud ja lamedavõitu.

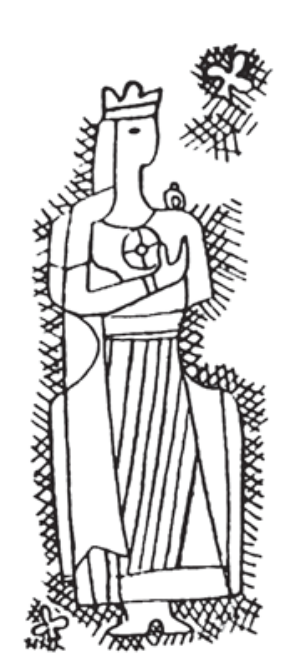

Joonis 3. Adamson-Ericu vinjett 1939. aasta Varamu 4. numbris, lk 420 .

Tallinna ajakirjadega tegi põgusalt koostööd maali- ja tarbekunstnik Adamson-Eric (Erich Adamson, 19021968), kelle kunstiharidus pärines Euroopa vabaakadeemiatest. Temaga seostuvad mõned olulised seigad eesti ajakirjandusgraafikas. Nimelt rakendas AdamsonEric julgelt loodus- ja rahvakunstimotiive ning kasutas abstraktseid geomeetrilisi kujundeid kõrvuti stiliseeritud inim-, linnu-ja loomakujutistega. Ajakirja Varamu 1939. aasta 4. number tutvustab Adamson-Ericu loomingut. Avaldatud on tema isikupärased julgelt stiliseeritud, pisut naivistlike inimkujutiste ja taimemotiividega vinjetid ning initsiaalid (joonis 3 ). Oma terviklikkuses on Adamson-Ericu tillukestes vinjettides palju rohkem nn rahvuslikku iseloomu, mida neil aastail kujutav-ja tarbekunstist otsiti, kui nii mõnegi teise kunstniku vöökirja-žanris (Adamson-Eric 1932: 599) esemetes. Eks ole tõsi, et rahvuslikku kunsti ei loo mitte väliste atribuutide ülekandmine rahvaloomingust, vaid eelkõige hingestatus ja kunstiliste vahendite (rütm, kompositsioon, tehnika jm) kasutamise oskus. Kui asutakse mustreid üle kandma teatud sihtidega, kannatab selle all lõpptulemus. Adamson-Eric oli üks neist kunstnikest, kes oskas rahvuslikule teemale läheneda vägagi loovalt.

Nagu eelnevast ülevaatest näha, pani Tallinna koolkond 1930. aastail tugeva aluse eesti kujundusgraafika edasisele arengule, tagades hariduse järjepide- 


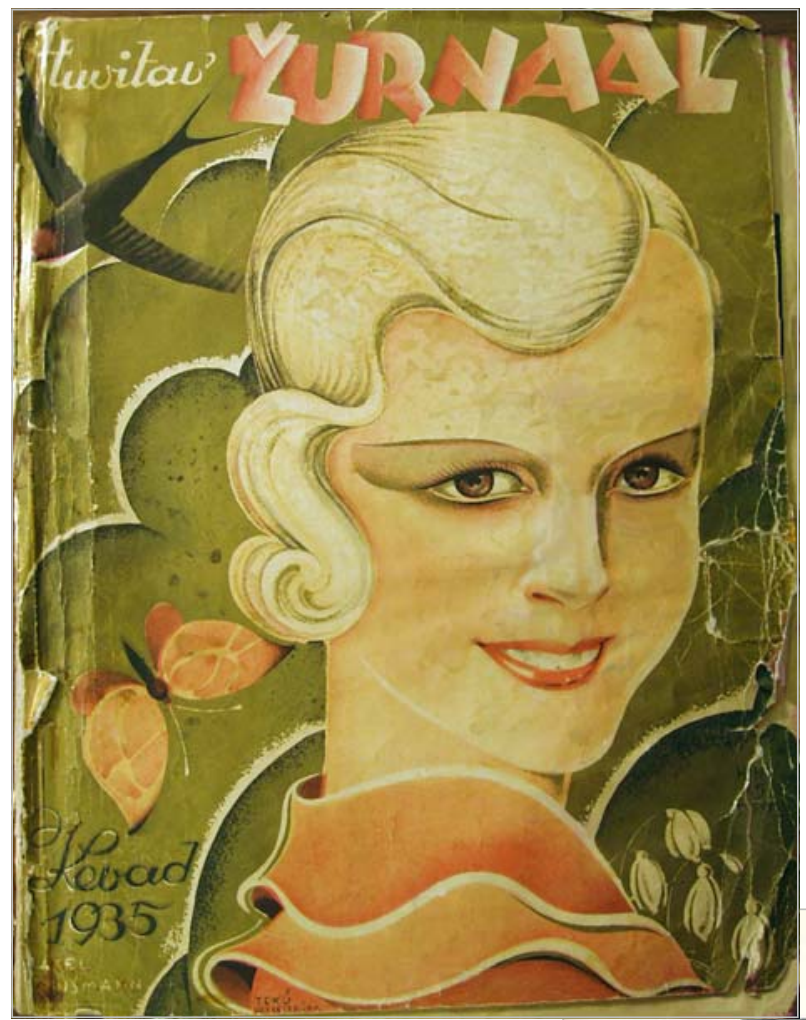

Joonis 4. Axel Rossman.

Huvitava Žurnaali 1935. aasta kevadnumbri kaas.

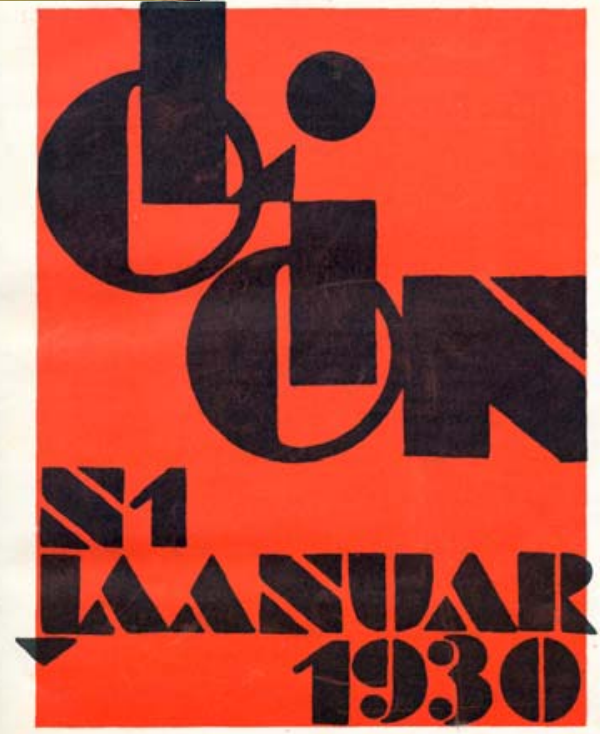

Joonis 5. Nikolai Triik ja Anna Triik-

Pôllusaar. Olioni 1930. aasta 1. numb-

ri kaas.

HIND SO SENTI 
vuse. Nagu muudel aladel, nii on ka tarbegraafikas täheldatav, kuidas juugendstiil kasvas vastavalt ajastu maitsele üle geometriseeritud elementidega art décoks. Teisalt püüdis noor rahvusriik rõhutada oma eripära ja selle parimaks võimaluseks arvati olevat etnilise ornamendi liitmine mõõdukalt klassikalise vormiga (Toom 2004: 68). Nii võibki öelda, et Riigi Kunsttööstuskooli põlvkonna kujunduslaadi iseloomustab art décolik stilisatsioon, mõõdukas rahvusliku elemendi (ornamendi või muu sümboolika) kasutamine ja tugev kompositsioon, mille aluseks oli süstemaatiline õpetus. Samuti on iseloomulik loogiliselt üles ehitatud selge ja loetav kiri. 1920. aastate graafilises disainis oli suurimaks puuduseks kirjakujunduse nõrk tase: kiri koos muu kujundusega ei loonud ühtset kompositsiooni. Mainitud puudus korvatakse 1930. aastail Riigi Kunsttööstuskoolis hariduse saanud graafikute loominguga.



Joonis 6. Ado Vabbe. Olioni 1930. aasta 4. numbri kaas. 




Joonis 7. Heino Lehepuu. Ajakirja Maret 1936. aasta 2. numbri kaas.

\section{Tartu koolkond}

Tartut eesotsas ülikooliga on alati peetud võimule vastanduvaks Eesti kultuurielu ja vaimsuse keskpunktiks. Võimu ja vaimu vastuoludest on palju räägitud kui igavesest ja fataalsest seaduspärasusest. 1930. aastail tõusis vaimu-võimu probleem üsna dramaatiliselt arutlusaineks (Andre et al. 1940). See oli aeg, mil suured ideed ja narratiivid valitsesid miljonite meeli, mil saksa vaimufilosoofide (eelkõige Friedrich Nietzsche) mõtted olid laialt tuntud ka Eestis (Ruutsoo 2002: 15-16). Kõrge enesehinnanguga vaimueliit oli valitsusega opositsioonis, rõhutades ja vahendades neile tähtsana tundunud väärtusi: demokraatliku vaimu sõltumatust võimust, eetikat ja kohusetunnet, kunsti kunsti pärast. Haritlasrüh- 


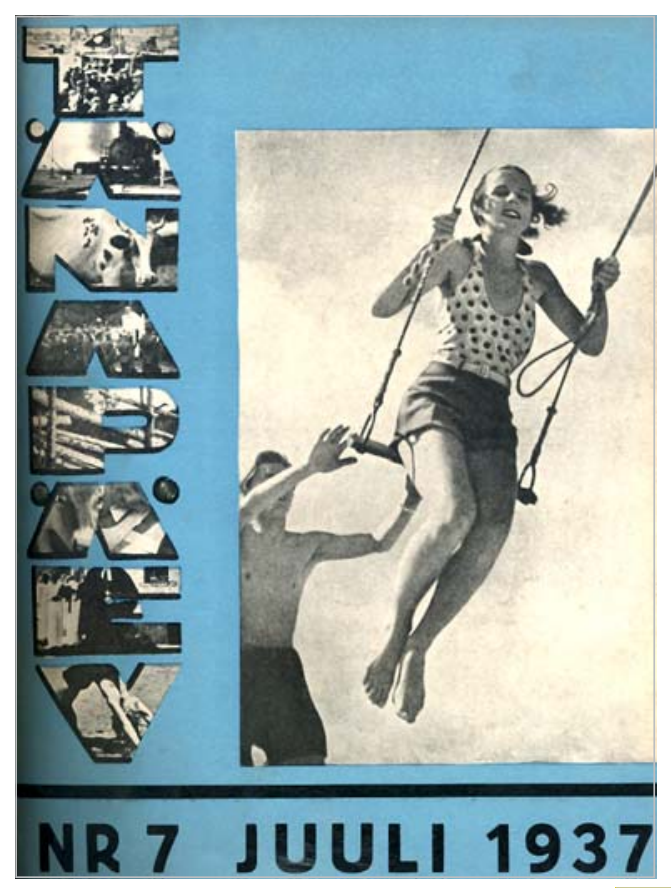

Joonis 8. Ernst Kollom. Ajakirja Tänapäev 1937. aasta 7. numbri kaas.

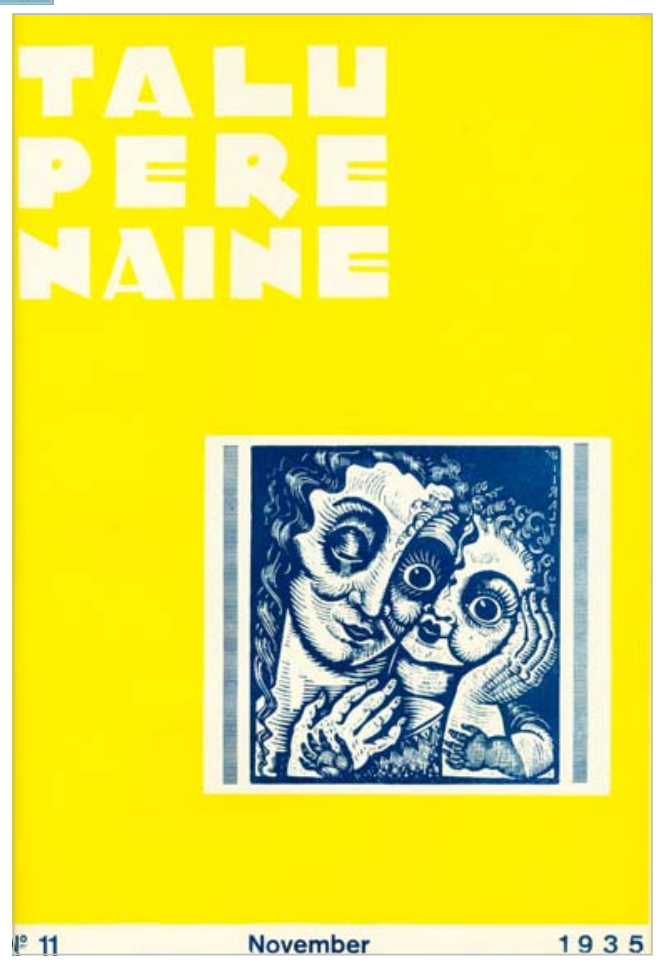

Joonis 9. Eduard Wiiralti puulõige Ema ja laps 1935. aasta Taluperenaise 11. numbri kaanel. 
mituste aktiivsus kasvas "vaikival ajastul" kuni avaliku vastasseisuni (Karjahärm \& Sirk 2001: 217). Tartu kujunes omapäraseks akadeemilise ja kunstnikuvabaduse koldeks. Pallaslane Endel Kõks on kirjutanud:

See oli linn, mis võttis vastu inimesi kõikjalt, ja aktsepteeris nende individuaalsed omadused, liites nende talendi oma vaimsusse ja muutis selle oma profiili üheks osaks (Kõks 1962: 91).

Nii pidi ka Tartu kunstikoolist Pallas kujunema õppeasutus, kus keskendutakse kujutava kunsti spetsiifilistele küsimustele ning hoidutakse poliitilistest probleemidest. Õppekava aluseks oli tugev natuuristuudium, toonitati professionaalsust ja arvestati iga ande iseärasusi.

1919. aastal kooli asutanud kunstiühing Pallas koosnes kunstnikest ja literaatidest, kelle vaimne kujunemine oli seotud Euroopa mitmekesise kultuurikogemusega. Kunstiühingu asutajaliikmeist viibisid Konrad Mägi, Ado Vabbe, Aleksander Tassa, Friedebert Tuglas jt 20. sajandi algusaastail Prantsusmaal, Hollandis, Belgias, Itaalias, Hispaanias, Soomes, Rootsis jm Euroopas. Niisugune laialdane kogemus andis hea aluse euroopalike õppekavadega kooli ülesehitamiseks, millest omakorda kasvas välja esimene aktiivne eesti moodsa kunsti põlvkond.

Alates 1924. aasta sügisest töötas kunstikool Pallas kõrgema õppeasutusena. See oli erakool, mille ülalpidajaks oli samanimeline kunstiühing. Sissetulekud sai kool õppemaksust, riigi ja omavalitsuse toetussummadest ning vabatahtlikest annetustest (Nurk 1977: 58). Seetõttu oli kooli majanduslik olukord võrdlemisi kitsas. Ainult säästliku majandamisega suudeti Pallast aasta-aastalt edasi viia. Vaatamata kitsastele aegadele võeti igal aastal eelarvesse 60000 marga suurune ühekordne välisstipendium ühele õppejõule. ${ }^{19}$ Silmaringi avardamise eesmärgil suunati välisreisidele ka parimaid Pallase tudengeid.

Pallase õppejõududeks võisid olla isikud, kes on lõpetanud mõne kõrgema kunstikooli. 1930. aastail võeti tööle juba oma kooli lõpetajaid. Vähese loomingulise potentsiaaliga õppejõud lülitati kooli tegevusest välja. Pallases peeti heaks tooniks teaduslikku kirjandust lugeda, seda enam, et linna kordumatu imago oli seotud Tartu Ülikooliga, kus kunstiõpilasedki võisid loenguil käia.

Erialane spetsialiseerumine Kõrgemas Kunstikoolis Pallas toimus ateljeedes. Ateljeevaliku nii eriala kui ka õppejõu osas tegi õpilane ise. 1930. aastate algul töötas ainult kaks maaliateljeed, mida juhatasid Nikolai Triik ja Ado Vabbe. 1930. aastast peale hakkas intensiivselt tööle graafikaateljee, mis oli aastaid olnud kooli valusamaid kohti. Graafikaateljeed hakkas juhatama A. Vabbe.

Kuna A. Vabbe töötas Pallases kokku 21 aastat(1919-1940) ja N. Triik 17 aastat (1921-1926 ja 1928-1940), võib edaspidi rääkida nende kahe kunstniku 
koolkondadest. A. Vabbe õpilane oli Hando Mugasto. Viimane asus graafikaateljeed juhendama 1935. aasta sügisel, kuid suri 1937. aasta kevadsuvel ja samal sügisel rakendati ateljees tööle Arkadio Laigo ja Roman Vaher. R. Vaher oli hea sügavtrükitehnikate valdaja, samuti oleks tal olnud võimeid õpetada kirjakunsti $^{20}$ (Toots 1970: 13), kuid tema väljendusviis oli korrektne ja asjalik ega avaldanud õpilastele erilist mõju. Seevastu leidis rohkesti jäljendajaid A. Laigo isikupärane figuurilaad. 1939. aasta sügisel lahkus R. Vaher Eestist ja töö graafikaateljees jäi ainult A. Laigo õlgadele (Nurk 1965: 35). Noorte pallaslaste suurteks eeskujudeks eesti graafikas olid seega eelkõige H. Mugasto ja A. Laigo, aga ka väga isikupärase stiiliga Eduard Wiiralt, kes töötas Pallases graafikaõppejõuna aastail 1924-1925. 1925. aastal sai E. Wiiralt aastase stipendiumi õpinguteks Pariisis, kuhu jäi kuni 1939. aastani.

1939. aastaks oli Pallase lõpetanud 64 õpilast, neist maali alal 49 (32 meest ja 17 naist), graafika alal kolm (üks mees ja kaks naist) ning skulptuuri alal 12 (kaheksa meest ja neli naist). 1940. aastani lõpetas Pallase ühtekokku 79 kunstnikku (Karjahärm \& Sirk 2001: 209). Võrdlusena olgu öeldud, et Riigi Kunsttööstuskooli lõpetas 1919.-1939. aastal 537 inimest, neist 205 kooli täiskursuse ja 322 töökodade astme (Karjahärm \& Sirk 2001: 209). Seega oli Tallinna koolkond arvuliselt mitu korda suurem. Ometi suutis just Tartu koolkonna lüürilis-poeetilise alatooniga looming luua rahvusvahelise ja rahvusliku kooskõla eesti kunstis. See oli eriti oluline kujutava kunsti aspektist vaadatuna. Tarbegraafikas oli pallaslaste käekiri võrreldes Tallinna kunstnike omaga maalilisem, isikupärasem, rohkem esines ekspressionismi (Eduard Wiiralt, Peet Aren) ja kubokonstruktivismi (Jaan Vahtra) mõjusid. Tartu kunstnike nõrgimaks küljeks oli kiri. Enamasti leidsid nad (ajakirjandusgraafika kontekstis eelkõige Ado Vabbe, Nikolai Triik ja Peet Aren) küll joonistega stiililt sobivad tähekombinatsioonid, kuid kirja osas rohkemaks ei olnud nad võimelised. Erandiks olid Hando Mugasto oma terviklike kirjalahendustega ja Jaan Vahtra, kes pakub arvukatel kaantel kubokonstruktivistlikele pindadele jaotatud raskepärast plokk-kirja või antiikvat. Sellise laadi harrastamine andis ka teiste kunstnike puhul (näiteks Ernst Kollom) häid tulemusi ja seda tuleb vaadelda kui ühte Bauhaus-stiili eesti varianti.

Suur osa Pallases kunstihariduse saanud kunstnikest hakkas tegutsema Tartus, tehes koostööd Tartus välja antavate ajakirjadega. Tartu oli tollal eesti raamatukants, kus asusid kõik tähtsamad kirjastused ja moodsaim graafikatööstus Ilutrükk.

Nikolai Triik (1884-1940) oli raamatute ja ajakirjade illustreerijana kahtlemata väga kogenud. Tema tööd äratasid tähelepanu juba 1905. aastal (NoorEesti I albumi kaas). 1930. aastail oli N. Triik tihedalt seotud Tartu ajakirja- 
dega Tänapäev ja Olion. Tänapäeva kaantel näeme art décolikku kompositsiooni ja figuuride lahendust. Mitme numbri kaanele on trükitud N. Triigi valmistatud kuulsad portreed-söejoonistused kultuuriinimestest (nt kirjanik Anton Hansen Tammsaare). Olioni esimese numbri (1930) kaanekujunduse valmistasid koostöös Nikolai Triik ja tema kolmas abikaasa ning õpilane Anna Triik-Põllusaar (1902-1999). See oli plakatlik kirjale tuginev kaas, mida ilmestas punane ristkülik (joonis 5). Sama kujundus veidi lihtsustatud kujul ilmus uuesti 1933. aastal, kusjuures igas ajakirjanumbris trükiti see erineva värviga.

1930. aastail hakkas N. Triigi ateljee regulaarselt lõpetajaid välja saatma, nende hulgas kunstnikud Ernst Kollom, Arkadio Laigo ja Richard Sagrits, kelle loomingul on siinkohal põhjust pikemalt peatuda.

Graafik Ernst Kollom (1908-1974) õppis N. Triigi ateljees aastail 1927-1931. Ta on eesti viljakamaid raamatugraafikuid, kes viljeles peamiselt tonaalset ja värvilist puugravüüri. Raamatute, aga ka ajakirjade kujundamisel taotles ta terviklikku üldmuljet. E. Kollom oli tohutult produktiivne, natuurilt realistlik puugravüürimeister. Tema tööd pole kompositsioonilt kuigi vaheldusrikkad, kuid on siiski maitsekad. E. Kollomi graveerimislaadis on tunda H. Mugasto mõjutusi. Lõikelaad on detailne, täpne ja puhas. E. Kollomi kaanekujundused ajakirjale Tänapäev on enamasti fotokompositsioonid. Oma ülesannet täidavad hästi 1937. aasta Tänapäeva 7. ja 8. numbri kaaned, millel kunstnik kasutab konstruktivistlikku pinnajaotust ja plokk-kirja, mis ühel juhul (nr 7/1937) moodustub fotokatketest (joonis 8). Viimane on, tõsi küll, kirjususe tõttu mõnevõrra raskesti loetav, kuid kompositsioonielemendina kahtlemata mõjuv. Fotokompositsioonid kaanekujundusena olid Euroopa ajakirjades tollal laialt levinud ja see kujundusliik kogus populaarsust Eestiski.

Arkadio Laigo (1901-1944) õppis aastail 1922-1927 Pallases Nikolai Triigi ja Peet Areni juures maalikunsti, lõpetades kooli praktilise kursuse, hiljem tegutses ise graafikaõppejõuna. A. Laigo loomingut iseloomustab mõõdukas kubistlik laad, André Lhote'i eeskuju. Graafikat hakkas Arkadio Laigo järjekindlalt viljelema 1933. aastal. Temast kujunes silmapaistev puugravüürimeister. Tema kompositsioon on rahulik ja tasakaalukas, vorm stiliseeritud. A. Laigo puugravüürid ilmusid vinjettidena ajakirja Tänapäev (1937-1939) lehekülgedel. Tema tegelaskujud on ränkjad ja massiivsete jäsemetega. Tema lõikelaad on jõuline ja kontrastne, ilma pehmete üleminekuteta.

Üks Pallase koolkonnale iseloomuliku maalilise laadi tooja ajakirjadesse oli Richard Sagrits (1910-1968). Ta alustas kunstiõpinguid 1928. aastal Riigi 
Kunsttööstuskoolis, kus õppis Roman Nymani juures dekoratsioonimaali ja Günther Reindorffi juures graafikat. 1930. aastal läks ta üle Pallasesse ja jätkas maaliõpinguid N. Triigi ning graafikaõpinguid A. Vabbe juhendusel. Kooli lõpetas R. Sagrits 1936. aastal. Ta avaldas tušijooniseid päiste ja illustratsioonidena Tänapäevas (1935). Nendes avaldub emotsionaalne maailmavaade ja ehe loodusetunnetus, mis iseloomustab Pallase koolkonda.

Teine oma koolkonnaga Pallase õppejõud oli Ado Vabbe (1892-1961). Tema kunstiharidus pärines Münchenist Anton Ažbé21 kunstikoolist. A. Vabbe ajavahemikus 1917-1940 illustreeritud raamatute arv ulatub üheksakümneni. Kaastöö ajakirjadele oli palju põgusam, kuid seejuures väga omanäoline ja meeldejääv. Tema töödes näeb futuristlikku dünaamikat, ekspressionistlikku tundlikkust ja kergelt snooblikku alatooni. A. Vabbe oli seotud Noor-Eesti traditsioonidega, Aubrey Beardsley ${ }^{22}$ ja Mir Iskusstva kunstimaailmaga. Ta tundis isiklikult Vassili Kandinskyt ${ }^{23}$ ja oli mõjutatud rühmituse Der Blauer Reiter ${ }^{24}$ abstraktsest ekspressionismist (Komissarov 1992: 7; Varblane 1994a: 183; Varblane 1994b: 1405). Sellest kõigest sünteesis ta oma stiili, mis on lähedane art décole. Tema liikuva rütmiga muretult vallatud tušijoonistused ilmusid kuukirjas Olion. Samasuguses muretus, pisut kergemeelseski laadis kujundas A. Vabbe Olioni 1930. aasta 4. numbri kaane (joonis 6).

A. Vabbe omapärane huvi must-valge kunsti vastu mõjutas kahtlemata ka tema õpilasi: eksperimenteerimishimu kandis ta üle ka neile. Ado Vabbe õpilastest tegutsesid ajakirjandusgraafika alal Elmar Kits (1913-1972), Hando Mugasto (1907-1937), Endel Kõks (1912-1983) ja Ott Kangilaski (1911-1975).

Elmar Kits õppis A. Vabbe ateljees aastail 1935-1939, graafikas oli ta Hando Mugasto õpilane. 1930. aastail kujundas noor Elmar Kits Tartus õpilasajakirju. Nendes leidub üsna huvitavaid linoollõiketehnikas kompositsioone, kuid kahjuks on kirja ülesehitus täiesti läbi mõtlemata, tähevormid juhuslikud. Kiri jääb veel mitmetes E. Kitse töödes nõrgimaks elemendiks. Küpse lahenduseni jõuab kunstnik 1937. aasta Kevadiku 2. numbri kaane puhul (joonis 10). Kiri ja piltkujutis sobituvad siin ekspressiivseks tervikuks. 1939. aastal andis E. Kits väikesi linoollõiketehnikas vinjette Tänapäevale. Siingi torkab silma rõõmus ekspressiivne lõikelaad.

A. Vabbe õpilastest oli graafiku ja kirjakunstnikuna andekaim Hando Mugasto (1907-1937). Aastail 1924-1933 õppis ta Pallases, aastail 1935-1937 töötas samas graafikaõppejõuna. H. Mugasto äkiline surm 1937. aasta 11. juunil vapustas avalikkust, tuues kaasa hulgaliselt järelehüüdeid ajalehtedes ja ajakirjades, koos ülevaateliste märkmetega tema loomingust (Kaal 1937; Pa- 


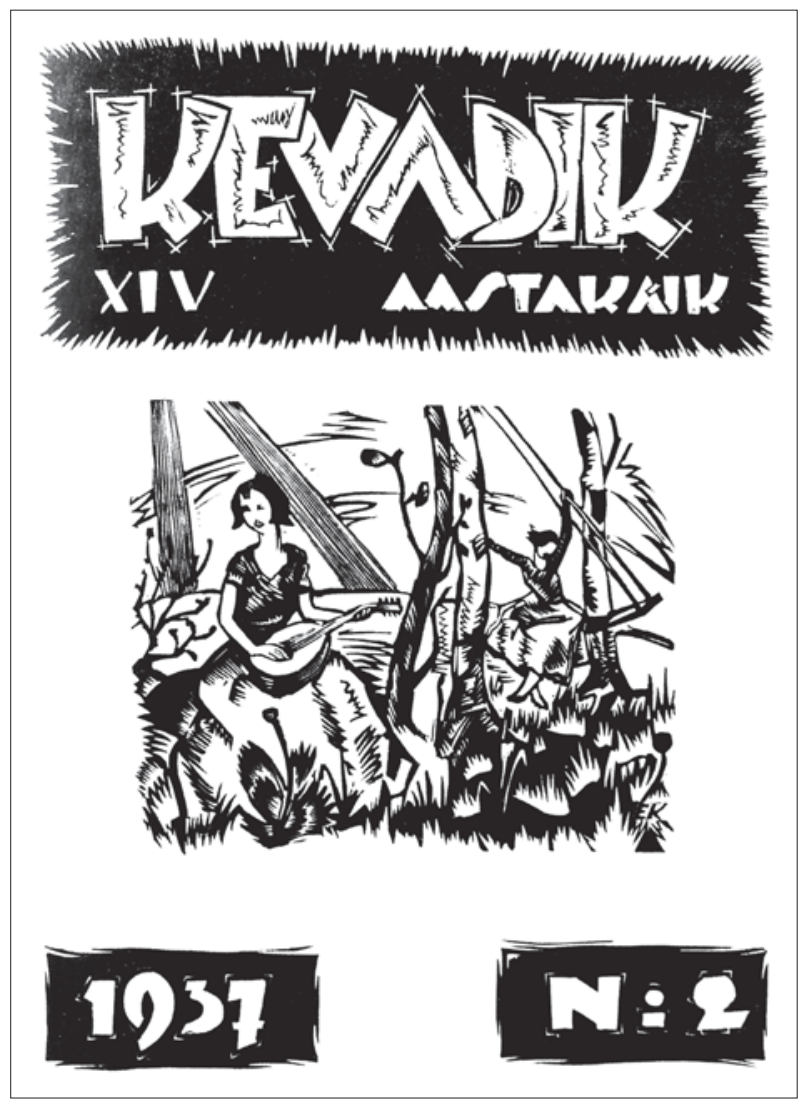

Joonis 10. Elmar Kits. 1937. aasta Kevadiku 2. numbri kaas.

ris 1937; R.P. 1937). Tänapäevas avaldati hulgaliselt H. Mugasto vinjette. Viimaste elu- ja tööaastate jooksul oli H. Mugasto kerkinud silmapaistvale kohale graafiku-puugraveerijana. Pallasesse asudes tundis ta kohe huvi graafika vastu. Tollal töötas Pallases graafikatöökoja juhatajana E. Wiiralt. Seega on E. Wiiralti mõju Hando Mugasto kunstnikupalge kujunemisel tegelikult otsustavam kui Ado Vabbe mõju. H. Mugasto omapärase ilmega looming kujunes just tänu E. Wiiralti kaugeleulatuvale eeskujule. H. Mugasto otsis tuge, tõuget, julgustamist ja õhutamist, mida pakkus meister oma eeskujuga (Kaal 1937: 367). Siit sai alguse H. Mugasto kompositsioonioskus ja mõtestatud vormikõne jälgimine paberil.

Olles erakordselt viljakas raamatugraafika alal, valmistas $\mathrm{H}$. Mugasto rohkesti vinjette ja kaunistusi muudelegi trükitoodetele. Sellega lõi ta hea traditsiooni originaalgraafilise loomingu vahetuks tutvustamiseks laialdastele rin- 
gidele. Hando Mugasto puulõiked ilmusid Tänapäeva (1936-1937), Varamu (1937) ja Olioni (1931) kujunduses. Enamasti ei ole need ajakirja tarvis tehtud joonised, vaid juba varem luulekogude illustratsioonidena avaldatud tööd. Ajakiri Teater Vanemuine ilmus aastail 1935-1938 H. Mugasto kaanekujundusega. Tegemist on vägagi küpse lahendusega. Kujundust iseloomustavad konstruktivistlik pinnajaotus ja art décolik kiri. Kirja alal oli H. Mugasto vaieldamatult tolle aja Tartu kunstnikest parim.

Noorte pallaslaste suur eeskuju Eduard Wiiralt (1898-1954) lõpetas Pallase 1924. aastal graafiku ja kujurina. Laskumata siinkohal E. Wiiralti erakordselt viljaka ja loomejärguti erineva loomingu süvaanalüüsi, tuleb mainida, et tema koostöö ajakirjadega peaaegu puudus. 1935. aastal ilmus Taluperenaise 11. number E. Wiiralt kaanejoonisega. Kaanepilt Ema ja laps (joonis 9) kujutab üht tüüpilist näidet $\mathrm{E}$. Wiiralti puulõikeloomingust. Pildil on ekspressionistlik kompositsioon - emal ja lapsel ühine silm ja pale, silmad ebaharilikult suured võrreldes suuvormidega, käed väikesed ja jooned rütmilisest lainetavad. Tõenäoliselt ei ole nimetatud gravüür tehtud spetsiaalselt ajakirjale.

Ajakirja Varamu 3. number aastast 1938 on pühendatud Eduard Wiiralti 40. juubelile. Ajakiri on täis E. Wiiralti tööde reproduktsioone ja kaunistatud tema vinjettidega. Vinjettides põimub ekspressiivne meelelisus sürrealistliku elemendiga. Oskar Looritsa teksti "Lind - eesti omakultuuri ja vaimsuse vapp" ilmestav inimnäoga linnu kujutis kannab endas nii õõvast salapära kui ka metafoorset tähendust. Korraks taaselustuvad siin kuulsa Põrgu (1930-1932) fantaasiakujud. Teatavasti tõrjus E. Wiiralt Pariisi-aastatel visalt kodumaalt tulevaid tellimustöid, mis mõjusid talle roiutavalt (Levin 1998: 69). Jüri Haini (1984: 64) hinnangul ei ole Eduard Wiiralt pärast Eestist lahkumist üldse ajakirjadega koostööd teinud ning Varamus on kasutatud kunstniku Pariisi-päevil valminud puugravüüre. Seetõttu võibki öelda, et E. Wiiralti panus eesti ajakirjandusgraafikasse üldse oli pigem kaudne kui otsene. Küll aga jõudsid E. Wiiralti illustratsioonid-puugravüürid 1927. aastal Prantsuse bibliofiilide ajakirja La Septimanie lehekülgedele (Levin 1998: 48). Kõige tuntum neist on Mai Levini andmeil illustratsioon Musitseerivad inglid, vähemtuntud mõtliku alatooniga töö Teelahkmel.

Märksa ulatuslikum oli aastail 1926-1930 Pallase õppejõuna töötanud Peet Areni (1889-1970) koostöö ajakirjadega. P. Aren sai kunstiharidust joonistamise, maalikunsti ja dekoratsioonimaali alal aastatel 1908-1913 Peterburis Kunstide Edendamise Seltsi koolis, ${ }^{25}$ hiljem täiendas end Viinis ja Münchenis. Maaliloominguga paralleelselt on Peet Aren kavandanud plakateid, ka- 
lendreid, brošüüre, raamatuid, ajakirju, eksliibriseid, finantsgraafikat. P. Areni varastes tarbegraafikatöödes avaldus Mir Iskusstva rahvusromantiline ja stiliseeriv laad, hiljem näeme ekspressionistlikku deformatsiooni ja art déco mõjusid. Saksa ekspressionismile omast kirglikkust ning sisu ja vormi ühtsust Peet Areni ajakirjandusgraafikas ei kohta. Välised, efektsed vormivõtted ei peida eneses sageli erilist sisemist laengut. 1930. aastate algul on tema kujunduste probleemseks elemendiks kiri. Järjekindlamat arengut kunstniku töödes näitab kirja muutumine üha kandvamaks ja selgemaks kujunduskomponendiks kümnendi teisel poolel. 1932. aasta Kevadiku 4. numbri kaane kujundus on segu ekspressionismist ja art décost, esineb nii ornament kui ka figuraalne kompositsioon, kuid sisulist sügavust joonisel ei ole. P. Areni parimaks tööks ajakirjandusgraafika vallas võib pidada kaane- ja sisekaunistusi lavakunsti ja kirjanduse kuukirja Teater kahele esimesele aastakäigule (1934-1935). Kunstniku kujundus moodustab meeldiva terviku, kuigi mõnel juhul jäävad siiski küsitavaks kirjatähtede proportsioonid.

Karin Luts (1904-1993) õppis Pallases aastatel 1922-1928. Isikupärane peen maalilisus ja eriline maailmatunnetus, mis domineerib tema õlimaaliloomingus, ei kandu otseselt ajakirjandusgraafikasse, kuid kindel stiilitunnetus iseloomustab tema vinjette ja initsiaale igal juhul. Ajakirjas Varamu on artiklite algul K. Lutsu joonistatud fantaasiaküllased initsiaalid ning numbrist numbrisse korduvad tema tillukesed vinjetid. Kunstnik põimib vöökirja- ja muud rahvuslikud motiivid osavalt ja loogiliselt ornamenteeritud initsiaalideks, ühendades rahvusliku traditsiooni pallasliku kunstikäsitlusega. Karin Luts oli ajakirjadega ka muul viisil seotud: ta joonistas rohkesti vaibamustreid Kodukäsitööle ning avaldas ajakirjanduses artikleid eesti ja välismaa kaasaegsest kunstist (vt ka Varblane 1994c).

Ajakirjandusgraafika seisukohalt on oluline Jaan Vahtra (1882-1947) looming. Eesti Kunstnikkude Rühma ${ }^{26}$ asutajaliige Jaan Vahtra käis aastatel 1912-1913 Riia kunstikoolis (õpetaja Vilhelms Purvītis ${ }^{27}$ ), õppis aastatel 1913-1916 Petrogradis Kunstide Edendamise Seltsi koolis ja seejärel aastani 1918 samas kunstiakadeemias. Peterburis puutus J. Vahtra kokku kubofuturismiga. Tema käsitluslaad muutus sünteesivamaks ja vorm hoogsalt liigendatuks. Kubistlik laad püsis J. Vahtra loomingus kõige kauem raamatukujunduses ja avaldus seal ka kõige järjekindlamalt (Peil 1972). Ajakirjandusgraafikas lõi J. Vahtra peamiselt kaanekujundusi, milles oli samuti säilinud konstruktivistlik laad. Kubism ja konstruktivism, mis vastandina ekspressionismi tundeväljendusele opereerib abstraktsete kujunditega, välistab tavaliselt igasuguse emotsiooni. Tähtis on ainult vorm, pindade ratsio- 
naalne organiseerimine, värvivahekordade mäng. J. Vahtra lähtuski nendest põhimõtetest. Ta saavutas lakooniliselt mõjuva üldmulje, väärtustades loetava ja selge kirja.

Alates 1936. aastast ilmus suur osa Noor-Eesti kirjastuse väljaandest Tänapäev Jaan Vahtra loodud kaanekompositsioonidega. Lihtsaim kujundusviis oli värvilise ja valge pinna abil poolitatud kaas, mille keskel asus loodus- või olustikufoto, üleval ja all joonistatud antiikvakiri. Selle kõrval näeme ka fantaasiaküllasemaid lahendusi. J. Vahtra konstrueeris ka rohkesti õnnestunud plakatkaasi, olles 1930. aastail üks produktiivsemaid ajakirjanduse illustreerijaid. Tema joonistel on jõuline joon, kuid samas on säilinud kindel kompositsioon ja loetav kiri. Ta puhastas kaanekujunduse liigsest detailirikkusest ja kuhjatusest.

Jaan Vahtra koolkonna esindajaks võib pidada Richard Kivitit (1888-1981), kes oli viljakas laste- ja noorsooraamatute ning lasteajakirjade kujundaja, kuid tema ajakirjades ilmunud looming oli šabloonne ja joonistuslikult keskpärane.

August Luiga (1906-?) astus Pallasesse 1937. aastal, kuid lõpetas 1947. aastal Tartu Riikliku Kunstiinstituudi. August Luiga 1935. aasta Olionis (vastavalt 8. ja 13. numbris) ilmunud linoollõiked Päikesetõus (joonis 11) ja Terrassil on

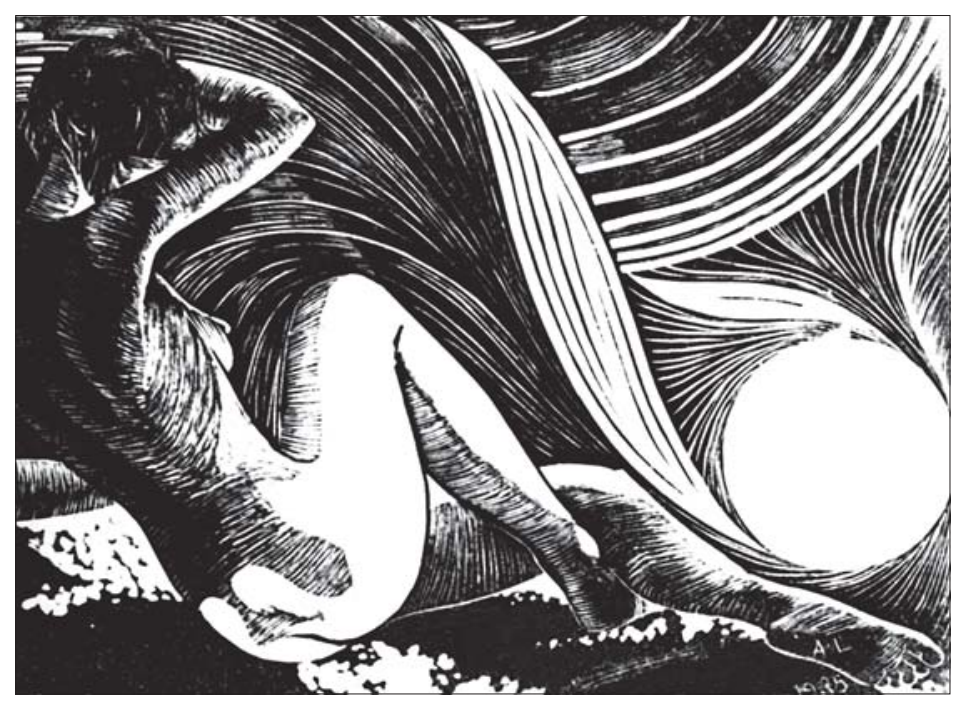

Joonis 11. August Luiga linoollõige Päikesetõus 1935. aasta Olioni 8. numbris lk 250. 
ehedaimad art déco näited Eesti ajakirjade illustratsioonide seas. Näeme stiilile omast dekoratiivsust ja peenusetaotlust. Nurgelised vormid ristuvad joonisel ümarustega. Stseenid ise on läbinisti romantilised.

Produktiivne graafik Agu Peerna (1904-1950) õppis Pallases aastail 19281932. Tema varased tööd on rahvusromantilises laadis, hiljem muutus käsitlusviis realistlikumaks, aga ka ekspressiivsemaks. Enim viljeles A. Peerna linoollõiget. Ta harrastas maalilisemat, robustsemat lõikelaadi kui H. Mugasto, A. Laigo ja E. Kollom. A. Peerna koostöö ajakirjadega algas 1920. aastail. Järgneval kümnendil avaldas ta monogravüüre Olionis (1932-1933) ning käsitöökavandeid ja kaanekujundusi Eesti Naises (1930-1935). A. Peerna lõi ka kaanekujundusi mitmetele laste- ja noorteajakirjadele. Tihe koostöö oli kunstnikul Tänapäevaga. Neid kaanekujundusi ja linoollõikes illustratsioone iseloomustab jämedakoeline, pisut ekspressiivne lõikelaad, mis muutis üsna mitme ajakirja välimuse nii mõnekski aastakäiguks meeldejäävaks ja on kokkuvõttes suhteliselt nauditav.

Eelnevatest näidetest lähtuvalt võib öelda, et Tartu koolkonna tugevuse moodustas just eelkõige erinevate kunstnike koostöö. Loomulikult töötas nii Tartu kui ka Tallinna ajakirjade juures ka rida karikaturiste, nagu Gori (Vello Agori, 1894-1944), Romulus Tiitus (1906-1982) ja Otto Krusten (1888-1937). Kuid et karikatuur on eeskätt publitsistlik žanr ja seotud eriti tihedalt oma aja päevaprobleemidega, tuleks seda vaadelda eraldi ja just poliitilises kontekstis.

\section{Autodidaktidest kunstnikud}

Lisaks kahele eespool käsitlust leidnud koolkonnale tegutses nii Tallinnas kui ka Tartus rida autodidaktidest kunstnikke, kellel kunstiharidus kas puudus üldse või piirdus juhuslike ja ebaprofessionaalsete kursustega. Autodidaktidest kunstnikud tegid ajakirjadele eelkõige reklaamgraafikat. Enamik ajakirjades avaldatud reklaamgraafikat on signeerimata, seega jäävadki autorid anonüümseiks, osalt on nad 1930. aastate reklaamiettevõtete varjatud töötajad. Järgnev ülevaade riivabki seetõttu vaid üht osa iseõppinud kujundusgraafikutest, nimelt neid, kelle loomingu kohta on õnnestunud koguda piisavalt teavet. ${ }^{28}$

Enamik iseõppinud tarbegraafikuid on loonud raamatugraafikat, ajalehekuulutusi, pakendeid, kaubamärke, buklette, äride vaateakende ning tööstus-, kaubandus-ja põllumajandusnäituste kujundusi. Nende loodud ajakirja- 
de kaanekujundused järgivad enamasti Lääne-Euroopa eeskujusid, kujutades armsaid, positiivse alatooniga olustikustseene. Enamasti on need värvikirevad figuraalsed kompositsioonid.

Iseloomulikuks näiteks on tolleaegse Tartu väljapaistvaima tarbegraafiku Heino Lehepuu (1907-1944) kaanejoonised ajakirjale Maret (1936) (joonis 7). Julius Genssi andmeil (1948: 72) kujundas H. Lehepuu 1930. aastail tosinkonna raamatu kaaned ja tegi ka siseillustratsioone. Kirjameistrina oli H. Lehepuu väga võimekas (tema loodud on ka Mareti tiitlikiri), kuid tegutsemine reklaamgraafika alal ei lasknud tema kirjakunstiandel täielikult avalduda.

H. Lehepuu koostöö ajakirjadega algas 1920. aastail. Tema laadi iseloomustab natuuritruu joonistus, tegelased - nii lapsed kui ka täiskasvanud - on armsate ümmarguste nägudega. 1930. aastate teisel poolel tegi ta seebireklaame A. Frederkingi seebivabrikule ${ }^{29}$ jt firmadele, samuti kujundas reklaamkuulutusi pudu- ja pesuärile Vennad Lepp. ${ }^{30}$ Neid avaldati ajakirjades Eesti Naine, Huvitav Žurnaal, Maret, Taluperenaine ja Teater Vanemuine. Osa neist on läbimõeldud kompositsiooniga plakatlikud lahendused. Seebireklaamide tugevaimaks küljeks on heal tasemel kiri ning romantiliselt kaunis piltkujutis. Mõnel juhul toob kunstnik sisse figuuri ja see muudab kujunduse magusaks. Siiski ei välju asi täielikult hea maitse piiridest ning mõjub pigem meeldivalt ja läbikomponeeritult.

Paul-Aleksander Pedersen (1906-?) oli rahvuselt norralane, kes õppis lühemat aega kunstnik Anatoli Kaigorodovi ${ }^{31}$ maalistuudios. Ta töötas aastail 19341944 reklaamikunstnikuna tolleaegsetes Eesti suurettevõtetes - tubakaettevõttes Laferme $^{32}$ ja šokolaadi-biskviidivabrikus Ginovker \& $\mathrm{Ko}^{33}$ (Genss 1948: 175; Raunam 1980-1990: 17). Nende kahe ettevõttega seotud reklaame avaldati 1930. aastate ajakirjades (nt Maret 1936-1937). P.-A. Pederseni reklaamkuulutusi iseloomustab dekoratiiv-graafiline peensus, näeme kunstnikule iseloomulikku antiikvakirja kombineerimist kursiivkirjaga ja natuurilähedast joonistust.

Tallinna ajakirjade juures tegutses kunstnikuna kirjandusteadlane Karl Taev (1903-1992). Ta tegi aastail 1936-1940 kaane- ja sisekujunduse ajakirjale Teater ning 1939. aasta Loomingu kaanekujunduse nõtke tähtkujudeseeriaga. K. Taev oli üsna hea joonistaja. Tema kunstnikutegevust ei ole siiani uuritud. Tema käekirja iseloomustab peen, tundlik tušijoonis.

Üldiselt kasutasid autodidaktidest kunstnikud kujundustes ja reklaamkuulutustel palju inimfiguure ja positiivseid naeratavaid nägusid, mis oli tavaline 




Joonis 12. Valter Kõrver. Kawe šokolaaditoodete reklaam ajakirja Kodu 1936. aasta 3. numbri tagakaanel.

ka Lääne-Euroopa, USA ning naabermaade Soome ja Läti ajakirjades. Ometi saavutati parem tulemus tihti just siis, kui loobuti figuurist. Seda näeme August Vahteli (1911-1943) kujundatud Põhjala kalosside (Teater, 1938), Frits Johansoni rätsepaäri (Rahvaleht, 1938) ja Laferme'i tubakatoodete reklaamidel. Viimased ilmusid ajakirjades Eesti Spordileht (1935), Maret (1938), Vallatu Magasin (1937), Huvitav Žurnaal (1937), Tänapäev (1939) ja Teater (1939). Kunstnikule on iseloomulikud graafiliselt peened täppide või lühikeste kriipsudega täidetud pinnad ning mustad siluettkujundid ja -figuurid.

Arvukad detailirikkalt joonistatud veini-, kohvi-, kosmeetikatoodete ja tubakapakendid esinevad reklaamidel ajakirjades Eesti Naine (1936), Teater (1936), Tänapäev (1936), Kaunis Kodu (1937), Huvitav Žurnaal (1936-1937), Talu- 
perenaine (1936), Sõdur (1934), Kodu (1936-1940) ja Eesti Kool (1937). Nende reklaamjooniste autoriteks on sarnase käekirjaga produktiivsed tarbegraafikud Karl Vanaveski (1909-1973) ning Valter Kõrver (1904-1941). Mõlema kunstniku loomingut iseloomustab graafiline dekoratiivsus. Seejuures ei ole Valter Kõrveri kompositsioon nii tihedalt organiseeritud ja detailirikas kui Karl Vanaveskil.V. Kõrver kasutab rohkem musti pindu, mis mõjuvad plakatlikult, figuraalsed lahendused on mõnikord maalilised, mis annab tunnistust heast joonistusoskusest. V. Kõrverile väga sarnases laadis reklaamkuulutuse leiab Saksamaal välja antud ajakirjast Lloyd Zeitung, mille levimise kohta Eestis annab kindla tõendi üksikute numbrite kättesaadavus Eesti antikvariaatidest (joonis 12).

Humoorika laadi esindaja eesti ajakirjandusgraafikas oli autodidaktist tarbegraafik Kaarel Joon (Jürgens, 1892-1981), kes oli mitme tubakaettevõtte kunstnik. Tema töid iseloomustab realistlik joonistuslaad, ta on ajakirjadele teinud hulgaliselt nägusaid päisliiste ja maameheliku huumoriga vürtsitatud illustratsioone.

\section{Kokkuvõtteks}

Kokkuvõtteks võib meenutada A. H. Tammsaaret, kes on öelnud, et Tartu on kuuvalguse, Tallinn autode linn, tabades "Tallinna võimu" ja "Tartu vaimu" müütide olemuse. Karin Hallase sõnul kujunes 20. sajandi algul Eestis kaks linnaimagot, millest alalhoidlikum, parem, humaansem, aga ka demokraatlikum ja boheemlikum oli Tartu, radikaalsem, ärilisem, ebamoraalsem, kuid samas suurlinlikum, modernsem ja euroopalikum Tallinn (Hallas 1995: 97). Mõlemas linnas oli oma kunstikool ja mõlema kooli kasvandikel oli oma loominguline nägu. Tartu koolkond andis palju huvitavaid ja isikupäraseid kunstnikke. Rahvuslik propaganda oli nende töödes vähem ilmne ja kunstnike loominguline vabadus suurem, kuid kiri oli süstemaatilise õpetuse puudumise tõttu sageli ebaprofessionaalne. Tallinna (Riigi) Kunsttööstuskooli õppekavade eeskujuks olid tarbekunsti profiiliga Peterburi Stieglitzi kunsttööstuskooli õppekavad, mida iseloomustas süsteemne kirja- ja ornamendiõpetus ning stilisatsioon. Ohtralt kasutatati etnograafilist ornamenti.

Ühiseks jooneks kahele koolkonnale kujunes art déco koos oma rafineeritud dekoratiivsuse ja salonglikkusega, stiilile olid iseloomulikud esinduslikkuse ja luksuslikkuse ambitsioonid koos avangardsete voolude taltsutatud ja mugandatud elementidega. Sellele lisandus nn vaikival ajastul hoo sisse saanud rahvuslikkuse propaganda, oma eestipärase stiili otsingud, millel oli olu- 
line roll nii pildis kui ka sõnas 1930. aastate ajakirjades, tõsi küll, rohkem Tallinna kui Tartu kontekstis. Tartu seevastu andis tõuke individuaalsuse esilekerkimiseks. Nõnda oligi meie ajakirjandusgraafika ilme üsna mitmekesine. Tegutsenud kaks koolkonda täiendasid teineteist edukalt. Eriilmelisus tekkis peamiselt tänu erinevatele individuaalsustele, milles oma osa oli öelda ka autodidaktidest kunstnikel.

\section{Kommentaarid}

${ }^{1}$ Rakenduskunstnike Ühing (RaKÜ) oli aastatel 1932-1940 tegutsenud eesti tarbekunstnike organisatsioon, mis ühendas tarbekunstnikke, soodustas nende loomingut ja kaitses kutsehuve. Ühing korraldas kaheksa näitust.

${ }^{2}$ Guido Mamberg (1895-1954) õppis Kopenhaagenis Kuningliku Taani Kunstiakadeemia kursustel, hiljem täiendas end Saksamaal, Rootsis, Austrias, Tšehhoslovakkias ja Inglismaal, kuulus mitmesse rahvusvahelisse tarbegraafikaseltsi. Tema töid on tutvustatud ajakirjades Gebrauchsgraphik, Advertising Display ja Dansk Reklame.

${ }^{3}$ Edmond Arnold Blumenfeldt (1903-1946) oli maali-, teatri- ja kujunduskunstnik. Ta õppis aastail 1920-1922 Berliinis Albert Reimanni (saksa skulptor-metallikunstnik; 1874-1976) tarbekunsti- ja teatridekoratsioonikoolis (Schule für angewandte Kunst Albert Reimanns, nn Reimann-Schule, asutatud 1902) ning täiendas end aastail 1923-1924 art déco pealinna Pariisi eraakadeemiates, töötades samal ajal teatridekoraatori ja reklaamikunstnikuna.

${ }^{4}$ Alexander Stieglitz omandas 1845. aastal Narva kalevimanufaktuuri ja rajas 1851. aastal Narva linaketramise manufaktuuri.

${ }^{5}$ Voldemar Päts oli sõjaeelse Eesti Vabariigi presidendi Konstantin Pätsi vend.

${ }^{6}$ Saksamaa vanim ja tänapäevani mainekamaid kunstikõrgkoole. Kannab 1947. aastast nime Leipzigi Graafika ja Raamatukunsti Ülikool (Hochschule für Grafik und Buchkunst Leipzig), asutati 1764. aastal maalimise, joonistamise ja arhitektuuriakadeemiana. 1901. aastal nimetati ümber Kuninglikuks Graafikakunsti ja Raamatukujunduse Akadeemiaks (Königliche Akademie für Graphische Künste und Buchgewerbe) (toim).

${ }^{7}$ Gerda Hoffman (1905-1947) on kujundanud näiteks 1924. aasta Laste Rõõmu 13. numbri kaane (toim).

${ }^{8}$ 1998. aastast Viini Kujutavate Kunstide Akadeemia (Die Akademie der bildenden Künste in Wien). 1692. aastal asutas õuekunstnik Peter Strudel (1660-1714) Viini Akadeemia erakoolina. 1725. aastal taasasutas Jakob van Schuppen kooli nime K.k. Hofakademie der Maler, Bildhauer und Baukunst all. 1772. aastal ühendati akadeemiaga kõik tolleaegsed Viini kunstiõppeasutused. 1872. aastal sai akadeemia kõrgema õppeasutuse staatuse, 1998. aastal koos praeguse nimega ülikooliks (toim).

9 Salome Trei (1905-1995), üks teedrajavaid eesti naiskunstnikke Agaate Veeberi (1901-1988), Aino Bachi (1901-1980) ja Ella Mätliku (1904-1943) kõrval. Tegeles Teise maailmasõja eel peamiselt graafikaga, hiljem paguluses ka raamatukujundusega. Näitused Eestis: Tallinna Kunstimuuseumis (1969), Adamson-Ericu Muuseumis (1995), Kuressaare lossis (1995) (toim). 
${ }^{10}$ Linda Ormesson (1902-1989) oli üks aastatel 1932-1933 ilmunud rahvaliku kodumajanduse ajakirja Maanaise Kodu peatoimetajaid, kodundusalaste käsiraamatute autor ja koostaja (toim).

11 Johanna Ormesson (ka Ormusson) on mh ka käsitööraamatu Heegeldamine, kudumine, fileetöö (Tallinn: A.R.T. Põllumajandusliit 1935) autor (toim).

${ }^{12}$ Kui 19. sajandi lõpul ja 20. sajandi algul ei pidanud illustratsioon olema uudne, siis 1920.-1930. aastatel muutus suhtumine välislaenudesse. Kunsttööstuskooli põlvkond moodustas esimese kodumaal koolitatud kujundajaskonna, mille tööle asudes välislaenud silmatorkavalt vähenesid.

${ }^{13}$ Mir Iskusstva ( инр uскyсcmba 'kunstimaailm') nime kandis 1890. aastate lõpul Peterburis tekkinud kunstirühmitus, samuti vene modernistliku kunsti ja kirjanduse arengus olulist rolli mänginud kultuuriajakiri (ilmus 1898-1904). Rühmitus kujunes välja gümnasistide eneseharimisühingust, kuhu algselt kuulusid tulevane kunstnik ja kunstiteadlane Alexandre Benois (1870-1960) literaat Dmitri Filosofov (18721940), kunstnikud Léon Bakst (1866-1924), Jevgeni (ka Eugene) Lansere (ka Lanceray; 1875-1946), Konstantin Somov (1869-1939) ja teatritegelane Sergei Djagilev (1872-1929), kellest peagi kujunes rühmituse liider ja ajakirja peatoimetaja. Esmakordselt tuli rühmitus avalikkuse ette 1898. aastal Soome ja Vene kunstnike ühisnäitusega. Järgnevatel näitustel liitusid rühmitusega Mihhail Vrubel (1856-1910) Isaak Levitan (1860-1900), Nikolai Roerich (1874-1947) jpt kunstnikud. Mir Iskusstva motoks oli puhas kunst ehk "kunst kunsti pärast”, millega nad vastandasid end nii ametlikule akadeemilisele kunstile kui ka peredvižnikute moraliseerivale realismile. Nende stiili kujunemisel mängisid tähtsat osa rahvusromantilised tendentsid, mis jätkasid eelmise kunstnikepõlvkonna vene stiili otsinguid. Tähtsamgi oli aga toetumine sümbolismi ja laiemalt neoromantismi poeetikale, samuti rühmituse programmiline "eurooplus". Sisemiste vastuolude tõttu lõpetas ühendus oma tegevuse 1903. aastal, mil suur osa selle liikmeid moodustasid koos Moskva maalijatega uue rühmituse - Vene Kunstnike Liidu. 1910. aastal astusid aga Peterburi kunstnikud eesotsas A. Benois'ga liidust välja ja lõid taas Mir Iskusstva. Uues koosseisus tegutses rühmitus 1924. aastani. Rühmitusel oli suur mõju Vene kunsti ja laiemalt modernistliku esteetika kujunemisele. Euroopa kunsti ajalukku kirjutasid Mir Iskusstva kunstnikud oma nimed eelkõige teatrikunsti uuendajatena (toim).

${ }^{14}$ Põhja-Eesti tikandi lillkiri, mida Günther Reindorff oma töödes kasutab, pärines tegelikult 17. sajandi barokk-kunstist. Barokk-kunstis puhkenud lopsakas naturalistlik dekoor, lilled, puuviljad ja linnud ei levinud mitte üksnes tikandeis, vaid idamaadest mõjustatud kudumeis, hõbeesemetel, maalingutes ja kiviskulptuuriski. Eksootilisi ja fantastilisi lilli ning puuvilju sisaldav lillkiri esineb eesti rahvakunstis baroki, rokokoo ja klassitsistliku stiili erivariantidena. Nagu linnakultuuriski, on see rahvakunstis läbi teinud kõik 17. ja 18. sajandi lillornamendi arenguetapid. Seda näeme linukatel ning käise- ja tanukirjades (Üprus 1969: 22).

15 Üldnimetus art déco (õieti arts déco = arts décoratifs) tähistab selgelt eraldatavat stiili dekoratiivkunstis, mis kerkis Euroopas esile vahetult enne Esimest maailmasõda ja jäi moepildis domineerivaks 1930. aastate lõpuni. Art déco kasvas välja mitmetest 20. sajandi alguse kunsti- ja disainivooludest, mille hulgas tuleb nimetada juugendit, Viini Secessioni, Saksa Werkbunds-disaini, vene konstruktivismi ja hollandi de Stijli (Sternau 1997: 10). 
${ }^{16}$ Bauhaus oli Saksamaal tegutsenud kunstikool, mille asutas arhitekt Walter Gropius (1883-1969) 1919. aastal Weimaris. 1925. aastal viidi kool Dessausse ja 1932. aastal Berliini, kus see 1933. aastal suleti. Bauhausiga seotud kunstnike ühine taotlus oli ületada tööstustoodete ja kunsti vaheline lõhe ning kujundada esemelist keskkonda ilu seaduste järgi. Bauhaus koolitas uut tüüpi mitmekülgseid kunstnikke disainereid -, kelle ülesanne oli kavandada tööstuslikku hulgitoodangut (mööblit, valgusteid, tekstiili, tapeete, keraamikat, metallitooteid jm). Bauhausis loodi ja õpetati kõiki visuaalseid kunste, kuid neid ühendavaks jõuks oli arhitektuur. Järgiti põhimõtet, mille järgi ehitiste või esemete vorm peab tulenema nende ülesannetest (funktsioonist), seega esindas Bauhaus kunstis ja keskkonnakujundamises funktsionalistlikku mõtlemisviisi. Tuntumad õppejõud olid arhitekt Hannes Meyer (18891954), karikaturist ja maalikunstnik Lyonel Feininger (1871-1956), uue värvusõpetuse looja Johannes Itten (1888-1967), esimesi abstraktsioniste Vassili Kandinsky (1866-1944), ekspressionistist maalikunstnik Paul Klee (1879-1940), arhitekt Ludwig Mies van der Rohe (1886-1969) ning kunstnik, disainer ja arhitekt László Moholy-Nagy (1895-1946).

17 Üks Eesti suuremaid tekstiilitööstusi A.-S. Oskar Kilgase trikoo-, pitsi ja sukavabrik (asutatud 1922) paiknes Tallinnas Volta 3, selle hooned hävitasid sakslaste eest taganevad punaarmeelased 1941. aastal. Vabrikus töötas pärast Kunsttööstuskooli lõpetamist 1929. aastast mustrikujundajana Johann Naha (toim).

${ }^{18}$ Höhere Graphische Fachschule der Stadt Berlin, asutatud 1895. aastal Berliini käsitöökooli graafika- ja trükiklassina, üks praeguse Berliini Kunstiülikooli (Universität der Künste Berlin) eelkäijaid (toim).

19 1921. aastal anti stipendium Konrad Mäe kasutada. Järgmisel suvel sõitis Saksamaale ja Kreekasse dekoratiivmaaliga tutvuma Ado Vabbe. 1923. aastal siirdus Saksamaale Anton Starkopf koos õpilaste-stipendiaatidega. 1924. aastal määrati A. Vabbele ühekordne toetus dekoratsioonimaali erialaga tutvumiseks Pariisis (Nurk 1977: 43).

20 Tarbegraafikat ega kirja Pallases otseselt ei õpetatud, sellest tuleneb ka Pallase kunstnike teatav ebakindlus kirja alal.

${ }^{21}$ Anton Ažbé(1862-1905), Saksamaal tegutsenud maalija ja kunstiõpetaja.Avas 1891. aastal Münchenis erakooli, mis pälvis väga hea maine. A. Vabbe õppis seal aastaid pärast kooli looja surma, kuid ajal, mil Münchenis tegutses samas koolis õppinud Vassili Kandinsky. Ažbé koolis (Ažbé-Schule) on õppinud näiteks vene päritolu kunstnikud Igor Grabar (1871-1960 ja Alexei von Jawlensky (1864-1941), aga ka sloveeni impressionist Matej Sterne (1870-1949), serblane Nadežda Petrović (1873-1915) ja horvaat Josip Račić (1885-1908), leedulane Mstislavas Dobužinskis (1875-1957) ja tšehh Ludvík Kuba (1863-1956) (toim).

${ }^{22}$ Aubrey Beardsley (1872-1898), inglise graafik, raamatuillustraator ja kirjanik. Sai maailmakuulsaks tänu mustvalgetele, väga ornamentaalsetele ja rütmilistele raamatuillustratsioonidele. Tema loomingule on iseloomulikud stiliseeritud dekoratiivsus ja elegants, sisult on tema joonistused aga tihti erootilised ja isegi perverssed. Tähtsaimad tööd on Alexander Pope'i ja Ben Johnsoni raamatute illustratsioonid. On mõjutanud raamatugraafikat ka väljaspool Inglismaad (toim).

${ }^{23}$ Vassili Kandinsky (1866-1944), Venemaal sündinud, kuid põhiliselt Saksamaal ja Prantsusmaal tegutsenud ekspressionist-maalikunstnik, graafik ja kunstiteoreetik, üks esimesi abstraktsioniste ja abstraktsionismi teoreetikuid. Osales rühmituste Phalanx (1901), Neue Künstlervereinigung (1909) ja Der Blauer Reiter (1911) asutamisel (toim). 
${ }^{24}$ Der Blauer Reiter (Sinine Ratsanik), Vassili Kandinsky eestvõttel 1911. aastal Münchenis asutatud saksa ja vene ekspressionistide rühmitus, mis sai nime asutaja samanimeliselt 1903. aastal loodud maalilt, millel romantiline kangelane ratsutab valgel hobusel läbi sügismaastiku. Rühmituse liikmeid ühendas huvi keskaegse kunsti ja primitivismi, aga ka nende kaasaegse prantsuse fovismi ja kubismi vastu. Rühmitusse kuulusid teiste hulgas Franz Marc (1880-1916), August Macke (1887-1914), Gabriele Münter (1877-1962), Alfred Kubin (1877-1959) ja Paul Klee (1879-1940), sellega olid lähedalt seotud Marianne von Werefkin (1860-1938), Alexej von Jawlensky (1864-1941) ja helilooja Arnold Schönberg (1874-1951) (toim).

${ }^{25}$ Aastatel 1906-1918 oli Peterburi Kunstide Edendamise Seltsi (Kunsti)kooli (Pucoвальная школа при обществе поошрения художеств) direktor vene maalikunstnik, ajaloolane, filosoof ja ühiskonnategelane Nikolai Roerich (1874-1947). Keiserlik Kunstide Edendamise Selts (Илиераторское общество поошрения художесть (ОПХ)) asutati 1820. aastal ja tegutses 1929. aastani. 1875. aastani kandis nime Kunstnike Edendamise Selts ( Общество поошрения художников). Seltsi kool loodi 1870. aastate keskel ja see tegutses 1929. aastani (toim).

${ }^{26}$ Eesti Kunstnikkude Rühm (ERK) - 1923. aastal loodud kunstiühing, mille liikmeid ühendas huvi kubokonstruktivismi vastu.

${ }^{27}$ Vilhelms Purvītis (1872-1945), 20. sajandi esimese poole silmapaistvaimaid läti kunstnikke, Peterburi Keiseliku Kunstiakadeemia akadeemik (1913), Riia Kunstiakadeemia esimene rektor (aastast 1921) (toim).

${ }^{28}$ Eesti kujundusgraafika ajaloos algab autorilooming 20. sajandi alguses. Ometi on seda üldisest kujundusgraafika produktsioonist võimalik kindlaks teha suhteliselt vähe. Tarbegraafika arenemise ja leviku aluseks on maa majanduse ja kaubanduse areng, mistõttu suur töömaht tingis vähevõimekate juurdevoolu ja (ilmselt töösturite soovitusel) välismaiste eeskujude matkimise, seda eriti tubakasaaduste pakendite ja reklaami osas.

${ }^{29}$ A. Frederkingi seebivabrik oli Tartu vanim seebitööstus, 1930. aastatel oli see juba Frederkingi perekonnalt läinud üle eestlaste valdusse, kuid kandis ikka veel vana nime (toim).

${ }^{30}$ Moe-, pudu- ja pesuäri Vennad Lepp avasid Karl ja Rudolf Lepp 1916. aastal Teises maailmasõjas hävinud Tartu Kaubahoovis (toim).

${ }^{31}$ Anatoli Kaigorodov (1878-1945), vene maalikunstnik, elas 1918. aastast Eestis, kust lahkus Anatol von Kaigorodovina (ta ema olnud friislanna) 1939. aastal Saksamaale (toim).

${ }^{32}$ A.-S. Laferme, tubakavabrik Tallinnas 20. sajandi esimesel poolel. Asus Pirita tee 20, samas hoones, kus praegu tegutseb ettevõtte mälestuseks sama nime kandvale äriühingule kuuluv Laferme'i pubi.

${ }^{33}$ Ginovker \& Ko, biskviidi- ja šokolaadivabrik Tallinnas, mille Josif Ginovker asutas 1906. aastal, oli Teise maailmasõja eelses Eestis Kawe järel suuruselt teine magusatootja. 1940. aastal liideti koos mitme teise ettevõttega Kawega, millest sai 1. aprillil 1948 Kalev (toim). 


\section{Arhiiviallikad}

ERA f 1108, n 6, s 843 = Eesti Rahvusarhiiv, fond 1108, nimistu 6, säilik 843 (Riigi Kunsttööstuskooli ja Riigi Kunsttööstuskooli juures asuva Trükitööstuskooli 1938/ 1939 õppeaasta tunnikavad, õppejõudude nimekirjad ja kirjavahetus. 1939).

Genss, Julius 1948. Eesti Kunsti materjale. 3. osa. Kunstnike leksikon. Tallinn. Käsikiri Eesti Rahvusraamatukogus.

Raunam, Oskar 1980-1990. Eesti tarbegraafika VI: Eesti tarbegraafikud. Eesti Kunstimuuseumi arhiiv, fond 30, nimistu 1, säilik 2 .

\section{Kirjandus}

Abel, Tiina 1995. "Pallase" koolkonnast 1930. aastate kunstiprotsesside foonil (Sissejuhatus koolkonna loomingu käsitlusse). Sarapik, Virve et al. (toim). Kunstiteaduslikke uurimusi $=$ Studies on Art and Architecture = Studien für Kunstwissenschaft 8. Tallinn: Eesti Kunstiteadlaste Ühing, lk 143-166.

Adamson-Eric 1932. Hispaania kiri eestilikkusest. Looming 5, lk 595-599.

Andre, Juhan et al. (toim) 1940. Vaim ja võim: Album Eesti Üliõpilaste Selts "Veljesto" 20-ks aastapäevaks. Eesti Üliõpilaste Selts "Veljesto" toimetused 3. Tartu: EÜS Veljesto kirjastus.

Bernštein, Boriss 1977. Kunsti rahvuslikust omapärast. Levin, Mai \& Lumiste, Mai (koost). Töid kunstiteaduse ja-kriitika alalt 2: Artiklite kogumik. Tallinn: Kunst, lk 1329.

Bernštein, Boriss 1979. Inimesekontseptsioon eesti kunstis. Bernštein, Boriss. Ringi sees ja ringist väljas. Tallinn: Kunst, lk 128-140.

Borsi, Franco 1987. The Monumental Era: European Architecture and Design, 19291939. New York: Rizzoli.

Hain, Jüri 1984. Eduard Viiralt rakendusgraafikuna. Kunst = Art in Estonia: Kujutava ja tarbekunsti almanahh 3 (65), lk 60-65.

Hallas, Karin 1995. Eestlane ja suurlinn. Sarapik, Virve et al. (toim). Kunstiteaduslikke uurimusi $=$ Studies on Art and Architecture $=$ Studien für Kunstwissenschaft 8. Tallinn: Eesti Kunstiteadlaste Ühing, lk 90-121.

Kaal, Aira 1937. Hando Mugasto inimesena. Tänapäev 12, lk 367-368.

Kalm, Mart 1994. Arhitekt Alar Kotli. Tallinn: Kunst.

Karjahärm, Toomas \& Sirk, Väino 2001. Vaim ja võim. Eesti haritlaskond 1917-1940. Tallinn: Argo.

Kirme, Kaalu 1975. Tallinna Kunsttööstuskool. Kunst = Art in Estonia: Kujutava ja tarbekunsti almanahh 1 (47), lk 14-17. 
Kirme, Kaalu 1994. Tallinna Kunsttööstuskool kui kunstihariduse andja. Kultuurileht, 11. november.

Kodres, Krista 2001. Ilus maja, kaunis ruum: Kujundusstiile Vana-Egiptusest tänapäevani. Tallinn: Prisma Prindi Kirjastus.

Komissarov, Eha 1992. Vabbe - helesinine ratsanik. Kunst = Art in Estonia: Kujutava ja tarbekunsti almanahh 3, lk 7-9.

Kõks, Endel 1962. Kilde Tartu profiilist: Tartu minevikust, olevikust, kirjanikest ja kunstnikest Pallase-päevilt. Tulimuld 2, lk 91-105.

Levin, Mai \& Sirkel, Enna (koost) 1989. Günther Reindorff 1889-1974: Sada aastat sünnist: Näituse kataloog. Tallinn: Eesti Kunstimuuseum.

Levin, Mai 1998. Eduard Wiiralt, 1898-1954. Tallinn: Eesti Kunstimuuseum.

Lotman, Juri 1999. Semiosfäärist. Avatud Eesti Raamat. Tallinn: Vagabund.

Nurk, Tiina 1965. Kõrgema kunstikooli "Pallas" osa eesti graafika arendamisel. Kunst = Art in Estonia: Kujutava ja tarbekunsti almanahh 2, lk 31-36.

Nurk, Tiina 1977. Kõrgem kunstikool "Pallas”, 1919-1940. Tallinn: Kunst.

Paris, Rudolf 1937. Hando Mugasto. Varamu 1, lk 98-101.

Peil, Mirjam 1972. Lõik eesti kunstist. Sirp ja Vasar 25 (1489), 23. juuni.

R.P. (= Paris, Rudolf) 1937. Mõtteid Hando Mugasto loomingust. Tänapäev 7, lk 219220 .

Ruutsoo, Rein 2002. Võimu vaimust ja vaimu võimust. Jarne, Aivar (peatoim). Riigikogu Toimetised (RiTo) 5. Tallinn: Riigikogu Kantselei, lk 13-23 (http://www.riigikogu. ee/rva/toimetised/rito5/artiklid/02ruutsoo.htm - 10. mai 2006).

Sakk, Ivar 2004. Eesti stiil - kas vene või saksa? = Estonian Style whether Russian or German? Kunst.ee: Kunsti ja visuaalkunsti kvartaliajakiri = Estonian Quarterly of Art and Visual Culture 3. Graafilise disaini lisa = Graphic Design Supplement 12, lk ii-xi.

Sternau, Susan A. 1997. Art Deco: Flights of Artistic Fancy. New York: Smithmark Publishers.

Talvik, Merle 2005. Riigi Kunsttööstuskooli põlvkond ajakirjade kujundajana 19301940. Talvik, Merle (koost). Kultuuriloost noorteadlaste pilguga 3: Artiklite kogumik. Tallinn: Tallinna Ülikooli Kirjastus, lk 119-148.

Toom, Maire 2004. Riigi Kunsttööstuskool 1914-1940. Eesti Kunstiakadeemia Toimetised 14. Tallinn: Eesti Kunstiakadeemia.

Toots, Villu 1970. Kirja osa eesti raamatugraafikas. Kunst = Art in Estonia: Kujutava ja tarbekunsti almanahh 2 (37), lk 10-21.

Varblane, Reet 1994a. Ado Vabbe ja moodne kunst. Sarapik, Virve (toim). Kunstiteaduslikke uurimusi = Studies on Art and Architecture = Studien für Kunstwissenschaft 7. Tallinn: Eesti Kunstiteadlaste Ühing, lk 180-198. 
Varblane, Reet 1994b. Avangardism ja traditsionaalsus Ado Vabbe loomingus. Looming 10, lk 1403-1418.

Varblane, Reet 1994c. Karin Luts - naine ja kunstnik mitmekordses paguluses. Rahva Hääl, 6. august.

Üprus, Helmi 1969. Eesti rahvakunst kunstiajaloo aspektist. Etnograafiamuuseumi aаstaraamat $=$ Ежегодник Этнографического лузея XXIV. Tallinn: Valgus, lk 7-36.

\section{Summary}

\section{Estonian Artists of Graphic Arts in Journalism in the 1930s}

\section{Merle Talvik}

Key words: graphic art in journals, art déco, Estonian art, calligraphy, Higher Art School Pallas, State School of Applied Arts, design graphics

The period of 1930-1940 marked the first surge of interest in graphic arts in Estonian journalism. The importance of artists who had received education in homeland increased and the following schools of specific creative image emerged - the school of Tallinn artists, who had mostly been educated at the State School of Applied Art, determined the face of magazines published in Tallinn (e.g. Muusikaleht, Huvitav -urnaal, Kirilind, Lood Elust, Maaomavalitsus, Teater, Välis-Eesti Almanak, Sõdur, Käsitööleht, Laste Rõõm, Kaitse Kodu!) and the Tartu school of graphic artists, who had been educated at the Higher Art School Pallas, designed the face of magazines and journals published in Tartu (e.g. Olion, Tänapäev, Varamu, Teater Vanemuine, Kevadik).Art déco style became the common feature of these two schools of art.

The curricula of the School of Applied Arts followed the example of curricula at the Stieglitz School of Applied Arts in St. Petersburg, which was oriented to systematic teaching in calligraphy and decorative art. The school had established good contacts with art institutions in Germany that were considered the most prestigious ones in Europe at the time. National ornamentation was abundantly used. In the $1930 \mathrm{~s}$, the Tallinn School laid a solid foundation for the development of Estonian graphic design by ensuring the continuity of education in this field. The work of the Tallinn school is characterised by art decoésque stilisation, moderate use of the element of nationalism and strong composition, also clear and legible script. The indisputable authority for this generation on both decorative art and calligraphy was Günther Reindorff (18891975), who devised the systematic methods in teaching calligraphy in Estonia. The most important representatives of the Tallinn school in the graphic art in journalism were Johann Naha (1902-1982), Paul Luhtein (born in 1909), Hugo Lepik (1905-2001), Werner Birkenfeldt (1903-1942), Eduard Salu (1906-1967), Ferdinand Liiv (19121948), Voldemar Tomassov (1906-1961), Axel Rossmann (1899-1974), Richard Pallas (1908-1951), Romulus Tiitus (1906-1982), Ferdinand Kask (1900-1941), Roman Haa- 
vamägi (1891-1964), Paul Liivak (1900-1942), Eugen Vaino (1909-1969) and AdamsonEric (1902-1968).

The Tartu school introduced many interesting and original artists; the national propaganda in these works was less evident and the artists had more creative freedom, although the quality of calligraphy was often unprofessional owing to the lack of systematic teaching. Nikolai Triik (1884-1940) and Ado Vabbe (1901-1944), two teachers of graphic art at the Pallas, had a major influence on the Tartu school. The former worked as graphic artist at journals, and his students Ernst Kollom (1908-1974), Arkadio Laigo (1901-1944) and Richard Sagrits (1910-1968) realised their potential in the field as well. Of the students of Ado Vabbe, graphic art in journals was fostered by Elmar Kits (1913-1975) and Hando Mugasto (1907-1937), the latter of whom was remarkably proficient at calligraphy in the Tartu school. Eduard Wiiralt (1898-1954), the great example of artists at the Art School Pallas, also belonged to the Tartu school.

In addition to educated graphic artists, there were several talented autodidacts active in the area. 